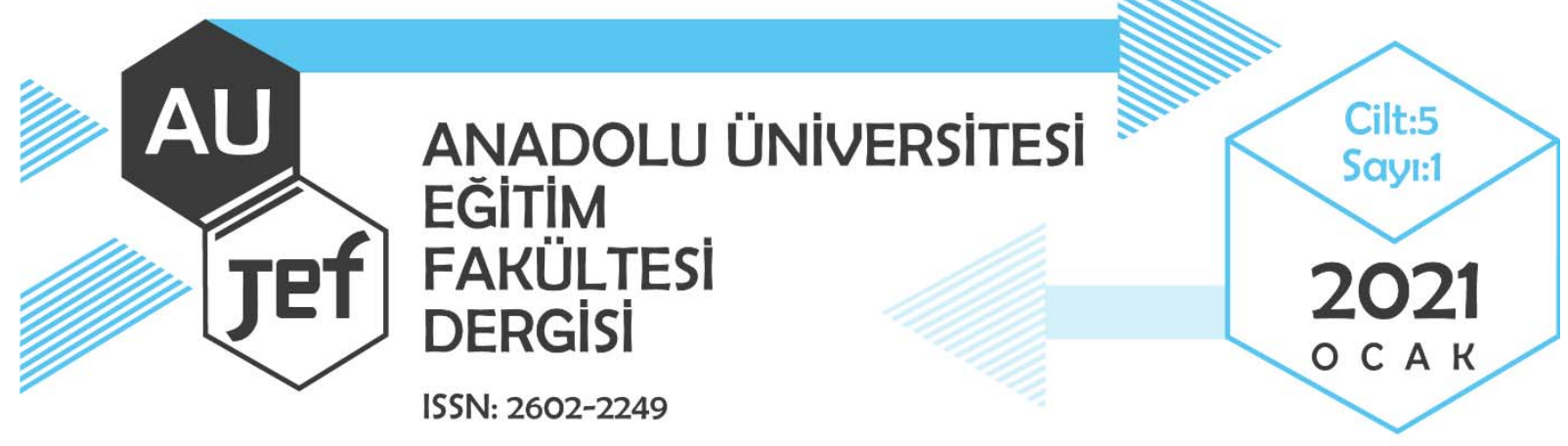

Transaksiyonel Analiz Terapisine Kapsamlı Bakış: Bir Derleme Çalışmasıı

\title{
Comprehensive Overview of Transactional Analysis Therapy: A Review Study
}

Saadet ZÜMBÜL ${ }^{1}$

Makale Türü²: Derleme

Başvuru Tarihi: 20.07 .2020

Kabul Tarihi: 11.01 .2021

Atıf İçin: Zümbül, S. (2021). Transaksiyonel analiz terapisine kapsamlı bakış: Bir derleme çalışması. Anadolu Üniversitesi Eğitim Fakültesi Dergisi (AUJEF), 5(1), 51-80.

ÖZ: Kişiler arası iletişim başta olmak üzere kişilik, gelişim ve psikopatolojiyi açıklamaya yönelik bir çerçeveye sahip olan Transaksiyonel Analiz Terapisi (TA) hümanizm, özerlik ve eşitliği temel alarak terapinin merkezine danışanı koyan bir terapi yaklaşımıdır. TA’nın iki temel amacı olduğu görülmektedir. Bunlar (i) bireylerin erken çocukluk dönemlerinde şekillenen ve hayat akışında süregelen ancak mevcut yaşamlarını aksatan çocukluk dönemi kararlarını diğer bir ifade ile yaşam senaryolarını değiştirmelerine yardım etme ve (ii) bireylerin kişiler arası ilişkilerinde ortaya çıkan sorunlar konusunda ortaya koydukları baskın yapılara farkındalık kazanmasına yardım etme. TA insan davranışlarıyla ilgili anlaşılması zor olan kavramları basit bir dil kullanarak açıklamış ve böylece günlük yaşamda kullanılabilir hale getirmiştir. Ülkemizde TA ve kavramları üzerine yapılan tezler olmasına karşın kapsamlı bir şekilde incelendiği sınırlı sayıda derleme çalışması vardır. Bu makalenin amacı TA’nın bütüncül bir gözden geçirmesini sunmaktır. Bu doğrultuda insan doğasına bakışı, temel kavramları, psikopatalojiye bakışı, terapötik amaçları, terapistin rolü ve işlevi, terapötik teknik ve yöntemlerine yer verilmiş ardından kapsamlı bir şekilde çok kültürlülük açısından değerlerdirmesini yapılarak yaklaşımın katkıları ile sınırlılıklarına değinilmiştir.

Anahtar sözcükler: Transaksiyonal Analiz, iletişim, terapi, derleme

ABSTRACT: Transactional Analysis Therapy (TA), which has a framework to explain personality, development and psychopathology, especially interpersonal communication, is a therapy approach that places the client at the center of therapy based on humanism, autonomy and equality. It is seen that TA has two aims. These are (i) to help individuals change their childhood scenarios, in other words, their life decisions that take shape in early childhood and continue in the flow of life but disrupt their current lives (ii) to help individuals become aware of the dominant structures that they present about problems that arise in interpersonal relationships. Therapy has explained the difficult concepts of human behavior in a simple language and thus makes it usable in everyday life. Among the studies conducted in our country, it is observed that TA has not find enough space for itself. In addition, there is limited amount of review study examining TA comprehensiveley. The aim of this article is to provide a holistic overview of TA. In this direction, the perspective of human nature, its basic concepts, view of psychopathology, therapeutic goals, the role and function of the therapist, therapeutic techniques and methods were included, and then the approach was evaluated in terms of multiculturalism and the limitations of the approach were mentioned.

Keywords: Transactional Analysis, communication, therapy, review

\footnotetext{
${ }^{1}$ Arş. Gör. Saadet Zümbül, Afyon Kocatepe Üniversitesi, Eğitim Fakültesi, Eğitim Bilimleri Bölümü, Rehberlik ve Psikolojik Danışmanlık Anabilim Dalı, szumbul@aku.edu.tr, ORCID: 0000-0002-3812-3482
} 


\section{GíRiş}

Transaksiyonel Analiz (TA) kişilik yapılanması, kişiler arası ilişkiler ve iletişim, gelişim, psikopatoloji, psikoterapi gibi çok geniş bir yelpazede insan psikolojisi ile ilgilenen bir yaklaşımdır (Akkoyun, 1995). Bu anlamda sistematik bir psikoterapi yöntemi olarak kabul edilmekte ve içinde bu sistematiği açıklamaya yönelik alt modellerden söz edilmektedir. Bir kişilik modeli olarak TA, öne sürdüğü üç farklı ego durumu arasındaki dinamikler yoluyla kişiliğin yapılanması ve işlevi ile psikolojik problemleri açıklamaya odaklanmaktadır (Johnsson, 2011). Bu açıdan yaklaşım, insanlarda evrensel olarak bulunan ve aynı zamanda devinim halinde olan yanların hangi durumlarda nasıl ortaya çıktığını ve bunların davranışlara nasıl etki ettiğini incelemektedir (Yılmaz, 2014). Kişiler arası ilişkiler de TA yaklaşımının ana odaklarından biridir. Bir iletişim modeli perspektifinden TA, kişiler arası ilişkilerin farklı transaksiyonlar, tanınma ihtiyacı ve biresel motivasyonlar temelinde analiz edelibileceğini öne sürmektedir (Johnsson, 2011). Senaryo modeliyle ise bireylerin ebeveynleriyle erken etkileşiminde gelişen bilinçdışı kalıplarının tarihsel bir analizine yer verilmektedir. Yaşam senaryosu, ebeveynlik öğretileri (komutlar ve karşı komutlar gibi) ile yaşama, kendine ve diğerlerine dair erken dönem kararların bir sonucu olarak yaşamın erken döneminde geliştirilir (Corey, 2016; Johnsson, 2011). Bağlantılı şekilde çocuklukta şekillenen kararların ve ileteşim kalıplarının artık işlevsel olmadığ 1 yetişkinlik döneminde yol açtığı problemler üzerinde duran Psikolojik Oyunlar modeliyle (Johnsson, 2011) ise psikolojik danışmada sürecinde de üzerinde önemle çalışılan ilişkisel sorunlar hakkında yaratıcı fikirler ortaya koymaktadır. Tüm bu perspektifler doğrultusunda bütüncül olarak TA'nın, bireylerin erken çocukluk dönemlerinde şekillenen ve süregelen ancak şu anki mevcut yaşamlarını aksatan çocukluk dönemi kararlarını ve yaşam senaryolarını nasıl değiştirebileceklerine odaklanarak kişiler arası ilişkilerinde ortaya çıkan sorunlar konusunda ortaya koydukları baskın yapılara karşı farkındalık kazandırmayı hedefleyen sistemli bir psikoterapi yöntemi sunduğu söylenebilir. Psikoterapi yöntemi olmasına ek ortaya koyduğu açık ve anlaşılır yapıyla farklı pek çok alanda adından söz ettiren bir yaklaşımdır. Örneğin sınıf içi etkileşim, sınıf yönetimi, anlaşmazlık çözümü gibi eğitim bilimcilerin de dikkatini çeken ve sahiplendiği bir yaklaşım olmuştur (Akbağ ve Deniz, 2003; Özerk, 2008).

TA geniş bir yelpazede insan psikolojisi ile ilgilenmekte, danışanlar için de anlaşılması ve günlük hayata uyarlanması pek çok terapi yöntemine göre daha basit olmaktadır. Ülkemizde TA ve kavramları üzerine yapılan tezler olmasına karşın kapsamlı bir şekilde incelendiği derleme çalışmalarının sayısı oldukça sınırlıdır. Bu makalenin amacı, Transaksiyonel Analiz Terapisinin insan doğasına bakışı, temel kavramları, psikopatalojiye bakışı, terapötik amaçları, terapistin işlevi ve rolü, terapötik teknik ve yöntemleri ile çok kültürlülüğe bakışını içine alan bütüncül bir gözden geçirmesini yapmak ayrıca katkıları ile sınırlılıklarını içerek şekilde terapinin bir değerlendirmesi sunmaktır. Bu amaçtan hareketle ülkemizde ve yurtdışında TA'yı tanıtan ve inceleyen araştırma makaleleri ve kitaplardan yararlanılarak sistemli bir literatür taraması yapılmıştır.

\subsection{Transaksiyonel Analiz Terapisinin Gelişimi}

TA, psikanaliz eğitimi almış olan Kanadalı psikiyatrist Eric Berne (1910-1970) tarafindan oluşturulmuştur (Clarkson, 1993a). Tarihsel olarak yaklaşımın felsefi ve düşünsel temelleri fenomenoloji, empirizm, varoluşçuluk ve hümanizme dayanmaktadır (Tudor ve Hobbes, 2007; Clarkson, 1993a). Psikanaliz eğitimi alan Berne, çalışmalarında Sigmund Freud'dan da oldukça etkilenmiştir (Söylemez, 2017). Ancak insanların sorunlarını çözmelerine yardımcı olmada psikanalizin yetersizliğinden duyduğu memnuniyetsizliğin TA'yı oluşturmasında ana etkenlerden biri olmuştur (Crey, 2016). Psikanalitik Yaklaşım insanların temel motivasyonun cinsellik dürtüleri ile bilinçdışı ve 
bilinçli güdüler arasındaki çatışmalardan kaynaklandığını, kişiliğin gelişiminin psikoseksüel evreler halinde yaşamın ilk 6 yılında tamamlanmış olduğunu ve kişiliğin id, ego ve süperego bileşenlerinden oluştuğunu öne sürmektedir (Murdock, 2016). İnsan gelişimine ilişkin bu önemli açıklamaların yanında yaklaşımda libido, eros-tenatos, ödipal çatışma vb. gibi pek çok alt kavramlar da yer almaktadır. Harris (2017)'e göre birçok klasik Psikanalitik Yaklaşımla ilgili en önemli sorunlardan biri, kavramların herkes için aynı anlama gelmiyor olmasıdır. Öyle ki teorisyenler arasında dahi egonun ne anlama geldiği konusunda tam bir fikir birliğinin olduğu söylenememektedir (Harris, 2017). Eric Berne Psikinalitik Yaklaşımdan açık bir şekilde etkilense de oluşturduğu TA yaklaşımında insan davranışlarıyla ilgili anlaşılması zor, kompleks fikirleri basit bir dille açılayabilecek bir sistem geliştirmiş ve bu kavramları günlük yaşamın her alanında kullanıma uygun hale getirmiştir (Akkoyun, 1993). Yaklaşımın en temel kavramlardan biri ego durumlarıdır. Ego durumlanı özünde Psikanalitik Yaklaşımın kişilik yapılanmasına dair alt kuramında yer alan id, ego ve süperego kavramlarına yakından benzemekte ancak bunlar sadece kuramsal ve soyut kavramlar iken TA'da ego durumları algısal ve deneyimsel gerçekliği yansıtmaktadır (Aydın 2015; Harris, 2017). TA Yaklaşımı Psikanalitik Kuramın ögeleri, Klein ve Fairbain'in Nesne İlişkileri Yaklaşımı, Sullivan'ın Kendilik Gelişimi, Federn'in Kişinin Fenomenolojik Gelişimi ve Erikson'ın Psikososyal Gelişim yaklaşımlarını yaratıcı bakış açısıyla sentezleyerek yeniden kavramlaştırmaktadır (Johnsson, 2011; Clarkson, 1993a; Aydın, 2015). TA Yaklaşımının sözü edilen klasik yaklaşımlardan pek çok noktada ayrıldığını belirtmek de önemlidir. Bu ayrımın en önemli noktası insan doğasına bakış açısıdır. TA, psikolojik danışma sürecinde danışan ve psikolojik danışman arasındaki güç dengesizliğini eşitlemekte aynı zamanda danışanı merkeze alarak sürecin aktif katılımcısı olmasını desteklemektedir (Clarkson, 1993a). İçgüdü kavramı reddedilmese de bunun çocuğun temel motivasyonun cinsel ya da yıkıcı dürtüler değil daha çok bakım verenleriyle (sevgi nesnesiyle) ilişki kurma ihtiyacı olduğu öne sürülmektedir. Bununla birlikte bireyin deneyimlerinin ebeveynleri tarafindan geçerli kılınma düzeyi, yetişkin olarak ihtiyaçlarını sağlıklı olarak karşılamasının da kritik bir ölçütü olmaktadır (Aydın, 2015). Yani çocukluk dönemindeki duygu ve düşüncelerin onaylandığı bir çevreye dikkat çekilmektedir. Tıpkı Adler gibi Berne de insanların çocukluk dönemlerinde hayatlarına rehberlik eden senaryolar şekillendirdiklerine inanmaktadır. Her ne kadar bu senaryolar erken dönem kararların ve etkileşim kalıplarının bilinçsizce şimdiki yaşamda tekrarlanmasına dayanıyor olsa da TA duygusal sağlık ve sorumluluğa odaklanırken bilinçdışının önemini azaltmaktadır (Seligman, 2010).

\section{2. İnsan Doğasına Bakış}

Her ne kadar psikanalitik mirasdan köken alsa da TA kuramı önemli ölçüde insan doğasına olumlu bakan hümanistik bir yaklaşımdır (Akkoyun, 1995; Clarkson, 1993b). Temelde Berne insan gelişiminde erken çocukluk döneminin ve ebeveyn mesajlarının önemini vurgulamıştır (Seligman, 2010). Ebeveynçocuk etkileşimi sırasında çocuğa temas iletileri aracılığıyla bir takım "izin" ve "yasaklar" iletilir ve çocuk kişisel-içsel çıkarımlar yaparak yamanın yönüne dair kararlar almaktadır (Corey, 2016).

TA'nın temel sayıltılarına göre tüm insanlar duygusal olarak gelişme, özerklik kazanma ve seçim yapma eğilimini taşır (Torun, 2015). Kuramın insan doğasına ilişkin temel varsayımları insan, yaşam ve değişim üzerine olan önermelerdir. Bu önermeler doğrultusunda TA'ya göre insanlar iyi olarak doğar (I'm OK-you're OK) ve her birey düşünme kapasitesine sahiptir. Erken dönem alınan kararlara yapılan vurgunun yanında değişim ile ilgili temel bir varsayım da insanların çocuklukta aldıkları ve tüm yaşamlarına yön veren kararların bir kurbanı olmadıkları isterlerse onları değiştirilebilecekleridir (Gökçen, 2009). Buradan hareketle TA yaklaşımının temel varsayımları şöyle sıralanmıştır (Akkoyun, 1995; Tudor, 2009): 
İnsanlar OKEY'dir: Herkes kim olursa olsun, ne yaparsa yapsın; değerlidir, anlamlıdır ve önemlidir. Kişiler arasında pek çok farklılıklar olmasına rağmen insan olarak herkes eşittir. İnsanlar sadece farklıdır ve bu farklılıklara rağmen her insan OKEY' dir. Bu psikolojik danışmada terapötik ilişkinin gerekli koşulları olan koşulsuz olumlu saygı ve bağl1lı̆̆ da ifade eder çünkü hem danışan hem de terapist için ortak bir OK olmanın varlığı söz konusudur.

Herkesin düşünme kapasitesi vardır: Önemli bir beyin hasarına sahip olmayan herkes hem çevrelerinde hem de kendilerinde ne olduğunu anlayabilme kapasitesine sahiptir.

Yaşamında ne olacağına herkes kendisi karar verir ve seçim yapabilir: Bağlam ve çevredeki diğer insanlar, birey üzerinde farklı etkilerde bulunabilir. Ancak hangi durumda olursa olsun, içinde bulunulan durumdan ne kadar ve ne şekilde etkileneceğine bununla birlikte nasıl bir tepkide bulunacağına bireyin kendisi karar verir. Bu öz-belirlemenin ve sorumluluğun temel değerini kabul etmektir.

Berne bu üç temel varsayımı kısaca "İnsanlar prens veya prenses olarak dünyaya gelirler, ancak sonradan kurbağaya dönüşürler. Terapinin amacı da yeniden prens veya prenses olmalarına yardımcı olmaktır." şeklinde mizahi tarzda özetlemiştir (Steiner, 1990; Akkoyun, 2007).

\subsection{Temel Kavramlar}

Transaksiyonel Analiz yaklaşımı; 1. Ego Durumları, 2. Temas İletileri, 3. Zamanın Yapılandırılması, 4.Yaşam Pozisyonları, 5. Yaşam Senaryosu ve 6. Transaksiyonlar olmak üzere altı öğeden oluşmaktadır (Akkoyun, 2007). Bu bölümde sıralananmış olan bu önemli teorik kavramlar ele alınmakla birlikte ayrıca yaklaşımda önemli bir yeri olan Egogram ve Sabitlik Hipotezi, Oyunlar, Çocukluk Kararları ve Sürdürücüler ile Raket Duygular kavramları da açıklanmıştır.

\subsubsection{Ego Durumları}

Ego durumları TA'nın en temel ve diğer kuramlardan da farklılı̆̆ını ortaya koyan en temel kavramıdır. Berne (1972) doğumdan hatta doğum öncesinden başlayarak, öznel yaşantıların her birinin bir "ego durumu" olduğunu belirtir. Ego durumları, kişisel gerçekliğini temel alan tutarlı duygu ve düşünce sistemleri ve bunlara karşılık gelen davranış kalıplarıyla ifade etmektedir (Berne, 1972; 2001). Diğer bir deyişle bir ego durumu, bir bireyin kişiliğinin bir kısmının belirli bir zamanda ortaya çıktığ bir dizi ilgili düşünce, duygu ve davranıştır (Corey, 2016). Berne (2001) ego durumlarını:

1. Ana-baba kişiliklerine benzeyen benlik durumları

2. Gerçeğin nesnel olarak değerlendirilmesine yönelik bağımsız olarak yöneltilmiş benlik durumları

3. Geçmişteki, ilk çocukluk yıllarını yansıtan davranışları sergileyen benlik durumları olarak açıklamış ve konuşma dilinle bunların sırasıyla Anne-baba, Yetişkin ve Çocuk durumları olarak tanımlanabileceğini ifade etmiştir.

Ego durumları kavramının kökleri ise Federn (1952)'in 'Ego Psikolojisi’ne dayanmaktır. Berne psikanaliz eğitimine devam ettiği sırada ilk analisti olan Paul Federn'in bazı ego durumlarının bireyin hafızasındaki şekliyle yaşandığ 1 ve sakladığını, belirli durumlarda da bunların tetiklenerek yeniden canlanabildiğini hipotezinden etkilenerek geliştirmiştir (Gökçen, 2009). TA bakış açısına göre her birey içinde kendi anne-babasını barındırmaktadır. Bu hayatın ilk beş yılında yaşanan en anlamlı içsel ve dışsal 
olayların hafızadaki kayıtları gibi düşünülebilir (Harris, 2017). Bir anlamda durumlar geçmişteki olayların kaydedilmiş bilgilerinin şu anki gerçek insanları, zamanı, mekanları, kararları ve aynı zamanda gerçek duyguları içererek şekilde yeniden kullanılıp davranışlara yön vermesidir (Harris, 2017). Bu bakımdan ego durumlarının içsel olduğu kadar davranışlarda kendini gösterebilen yaşantısal fenomenler olduğu söylenebilir. Nitekim Ego durumları kişiliğin dışında ayrı bir yerde yer alan soyut bir kavram olmadığı gibi daha önce de değinildiği gibi "id, ego ve süperego" kavramlarıyla eş anlamlı değildir. Çünkü Psikanalizde bunlar soyut ve hipotetik yapılardır ancak TA'da ego durumları farklı davranışlarda gözlemlenebilir ve tanımlanabilir (Johnsson, 2011). Ayrıca bu yapılar birer genelleme değil her bireyin biricikliğinde ifade bulan kişisel kişisel tarihine ve gelişimine dayanmaktadır. En önemlisi de durağan değildir değişimleri mümkündür (Johnsson, 2011).

Yaklaşımda ego durumları, yapısal analiz ve transaksiyonel/işlemsel analiz olmak üzere iki ayrı modelde incelenir. Yapısal analiz, ego durumlarının içeriği yani kayıtlı anılar ve stratejilerle ilgili olup intrapisişik ilişkiler bağlamında kişiliğin açıklanmasında, işlemsel analiz ise belirli bir etkileşim veya işlem etkileşim sırasında her bir bireyde hangi belirli ego durumunun aktif olduğu ve bunların ilgili kişiler tarafindan algılanması veya yanlış algılanması nedeniyle ortaya çıkan anlayış veya yanlış anlamaların teşhisini ifade eder. Yani ego durumlarının iletişimine yansıyan gözlemlenebilir kısımlarıdır (Akkoyun, 2011; Berne, 1958).

\subsubsection{Yapısal Analiz}

Yapısal analizin temeli ego durumları kavramıdır. TA'ya göre her bireyin kişiliği çeşitli bölümlerden oluşmaktadır, bunlar: Ebeveyn, Yetişkin ve Çocuk ego durumlarıdır (Solomon, 2003). En temelde bireyin kim olduğu, neden bu şekilde davrandığ varoşuluşsal soruları yanıtlamasına yardımcı eden yapısal analiz, bireyin düşüncelerini, duygularını ve davranışlarını ego durumları modelinde çözümlemesidir (Yılmaz, 2014).

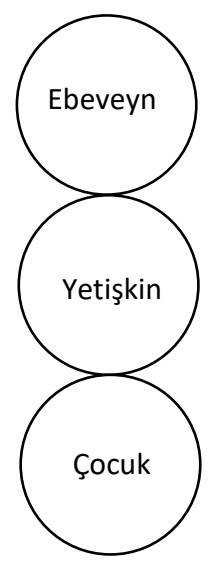

Şekil 1: Ego Durumlarının Yapısal Analizi (Harris, 2017).

\subsection{Ebeveyn Ego Durumu}

Bireyin yaşamındaki ebeveynlerinden ya da diğer ebeveyn figürlerinden öğrendiği veya ödünç aldığı bir dizi duygu, düşünce ve davranış kalıpları Ebeveyn ego durumu olarak ifade edilir (Keçeci, 2007b; Solomon, 2003). 


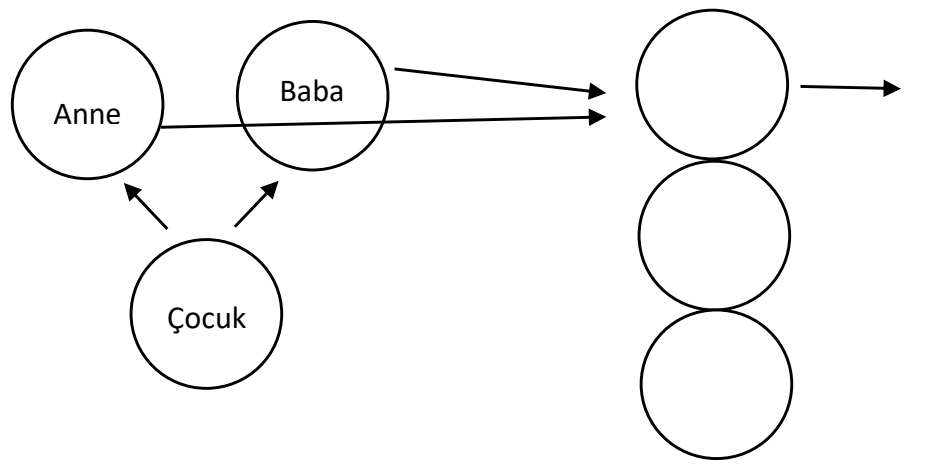

Anne ve baba, çocuk konuşur ve davranırken gözlemlenen kayıtlar çocuk tarafindan içselleştirilir. Bu kısım doğum ve beş yaş arasında çocuk Ebeveyn tarafindan algilanan dayatılmış, sorgulanmamış dış olayların kayıtlarıdır.

Şekil 2: Ebeveyn Ego Durumu (Harris, 2017).

Değinildiği gibi Berne (2001) "her insan kendi anne ve babasını içinde taşır” demiştir. Bu anlamda Ebeveyn; insanın kabaca ilk beş yılı olarak kabul edilen erken yaşlarında sorgulamaksızın kabul edilmiş ya da dayatılmış dış olayların beyindeki biricik kalıpları, diğer deyişle yansımalarıdır (Harris, 2017). Çocuğun bakım vericilerinden hayat boyu duyduğu ve gördüğü davranışlar, uyarılar ve kurallar Ebeveyn ego durumunda işlenmekte ve adeta kayıt altına alınmaktadır (Yılmaz, 2014). Ebeveyne alınan bilgilerin doğrudan düzenlenmeden alındığına işaret edilmiş̧tir. Bunun nedeni mesajın iyi, kötü vb. olması değil doğrudan güvenilir bir dayanaktan geliyor olmasıdır. Öyle ki bu mesajlar en erken ebeveyn iletişiminden başlayarak sözsüz olarak ses, tonu, yüz ifadesi, kucaklama ya da kucaklamamalardan daha örtük kurallara kadar uzanmaktadır (Harris, 2017). Ebeveyn ego durumundayken insanlar ebeveynlerinin yaşadıkları andaki olaya nasıl tepki vermiş olabileceğini düşünerek durumlara tepki gösterir veya ebeveynlerinin kendisine karşı davrandığ 1 şekilde başkalarına karşı hareket edebilirler (Corey, 2016). Tüm bunlara ek ebeveynin iki önemli işlevi de vardır: insan neslinin sürdürülmesinde yani ilki bireylerin kendi çocuklarını yetiştirirken etken olmasında fayda sağlar. İkincisi ise pek çok karmaşık karar almada ve davranış sergilemede kısa yolları, otomatik tepkileri sağlamasıdır ki böylece pek çok zaman ve güç tasarrufu sağlanır (Berne, 2001). Ebeveyn verisinin büyük bir yük ya da nimet olup olmaması bugüne uygunluğuna ve Yetişkin ego tarafindan güncelleştirilip güncelleştirmemesine bağlı olmaktadır (Harris, 2017).

\subsubsection{2. Çocuk Ego Durumu}

Çocuk ego durumu, çocukluktan itibaren sahip olunan tüm duygu, düşünce ve deneyimleri içeren “anılarının” bir parçasıdır (Solomon, 2003). Diğer bir deyişle çocuğun erken gelişimsel dönemlerindeki içsel ve dışsal tüm yaşantılarının kayıtları barındıran kısımdır (Yılmaz, 2014). Bireylerin yetişkinlik dönemlerinde ortaya çıkan bazı çocuksu olma yolları Çocuk ego durumlarının yansımasıdır (Solomon, 2003). 


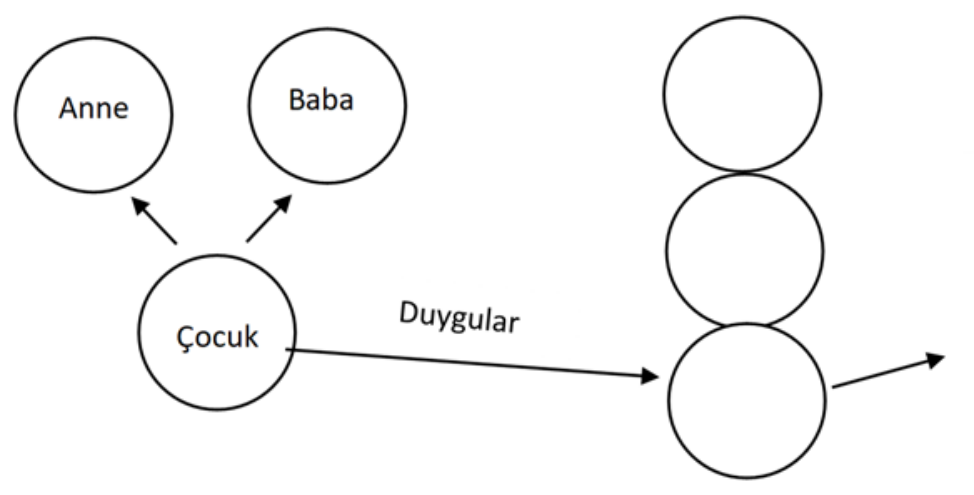

Doğum- beș yaş arası özellikle anne-babadan gelen diş olaylara verilen yanitlardan olușan iç olayların/duyguların ve kayitların/hissedilen yaşam kavramı

Şekil 3: Çocuk Ego Durumu (Harris, 2017).

Küçük çocuğun sözcük dağarcığı yetersiz olduğu için tepkilerinin çoğu duygularından oluşur (Harris, 2017). Çocuk küçüktür, bağımlıdır, beceriksizdir, sakardır, anlam kurabileceği kelimelerden yoksundur (Torun, 2015). Emerson "ters bir bakışın" nasıl değerlendirileceğini bilmek zorunda olduğumuzu söylemektedir. Bunun nasıl yapılacağını bilmeyen çocuğa yöneltilen ters bir bakış, onun kendisiyle ilgili olumsuz verilerine yeni veriler eklemektedir: "Bu benim hatam, hep, her zaman böyle olur ve sonsuza kadar böyle olacak" (Harris, 2017). Aynı zamanda çocuklukta sezgi, yaratıcılık ve kendiliğinden dürtü ve eğlence yerleşik özelliklerdir (Berne, 2001). Her bireyin içinde bir zamanlar çocukluğunda olduğu gibi hisseden, davranan, düşünen bir yönü vardır. İşte bu yön çocuk ego durumunu yansıtmakta ve kişinin yaşamının belli bir zamanında olduğu çocuğu temsil etmektedir (Yılmaz, 2014).

\subsection{Yetişkin Ego Durumu}

Yetişkin ego durumu diğer iki ego durumundan gelen mesajları gözlemleyerek dikkat alanına alan ve kabul eden ego durumudur. Veri işleme merkezine benzetilmektedir çünkü ego durumlarından gelen verileri diğer ego durumlarından tarafsız bir şekilde gören, işiten, düşünen ve doğru işleyebilen, sorunlara sadece önyargılarla veya çocuksu duygularıyla değil dış gerçeklikle de bakabilen yönü ifade etmektedir (Solomon, 2003). Ayrıca "şimdi ve burada"yı izleyerek olasılık ve alternatifleri de değerlendirdiğine değinmiş̦tir (Aydın, 2015).

Yetişkin ego durumu kronolojik yaşla ilgili değildir. Yetişkin, mevcut gerçekliğe yönelik bir düşünme durumudur (Corey, 2016). Yetişkin ego durumu bireyin yaşamını sürdürebilmesi, değişim ve zorluklarla başa çıkabilmesi için gerekli bilgileri, süreçleri ve hesaplamaları yapması bakımından önemlidir (Berne, 2001). Bir diğer önemli işlevi de ebeveyndeki veriyi inceleyerek doğru olup olmadığına ve bugüne uyup uymadığına bakmak sonra kabul veya reddetmektir. Ancak amaç onlardan kurtulmak değil bu verileri incelemek ve onların kontrolünden çıkıp özgür olmaktır (Harris, 2017). Yetişkin genellikle Çocuğun istekleri ve Ebeveynlerin istekleri arasında müzakere eder (Corey, 2016). Kısacası mevcut gerçeğe uygun ve diğer iki egonun verilerinden özerk olan duygu, düşünce ve davranış örüntülerini yansıtmaktadır (Widdowson, 2016). 


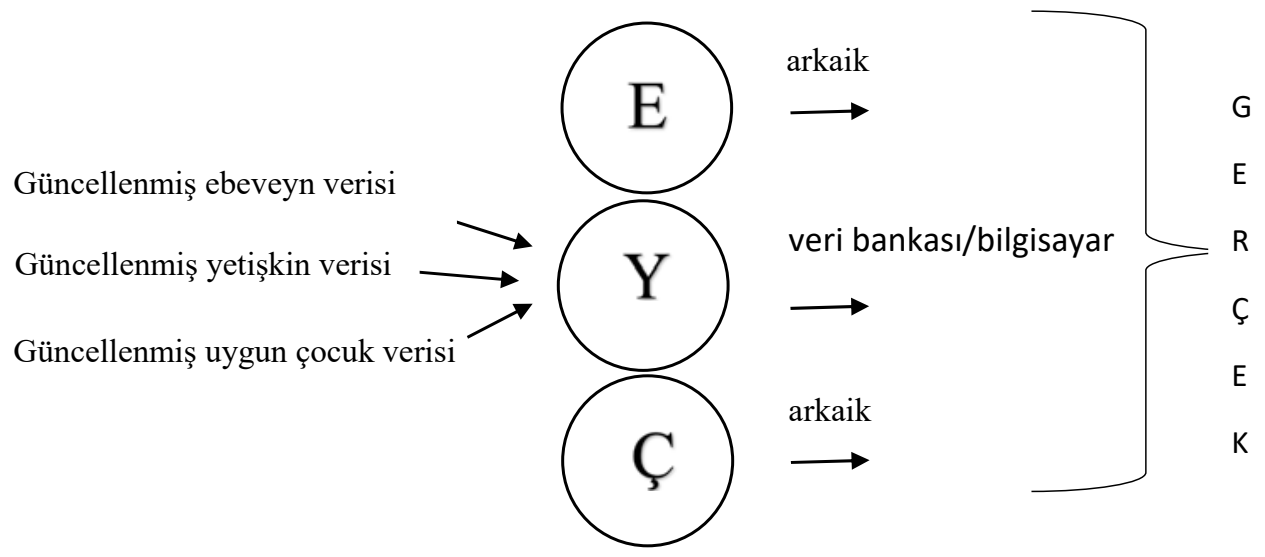

Şekil 4: Yetişkinin Üç Kaynaktan Veri Toplama Modeli (Harris, 2017).

Ego durumlarındaki değişimleri fark etme becerisi TA'nın temel bir uygulama pratiğidir. Eric Berne (1961) ego durumlarını tanımlama için 4 yöntem listelemiştir (Akt: Stewart, 2013): 1.Davranışsal, 2.Sosyal, 3.Tarihsel, 4.Fenomenolojik. Her bir ego durumu sözel ve sözel olmayan göstergeler temelinde gözlemlenerek ayırt edilebilir. Örneğin Ebeveyn, beden dili olarak sabırsız ve öfkelidir, otoriter jest ve mimikler sergiler ve sıklıkla "asla", "her zaman", "ilk ve son kez" gibi eleştirel ve yargılayıcı kelimler kullanır. Yetişkin, daha geçici ve uyumludur, "neden”, "nasıll”, “öyle anlıyorum ki” gibi kelimeler ve sorular kullanır. Çocuk ise tamamen üzüntü, hayal kırıklı̆̆ı, eğlence gibi duygulardan oluşmakta ve bunları omuzları sallama, gülme, ağlama gibi sözsüz davranışlarla göstermektedir. Çoğunlukla "istiyorum", "umurumda değil” gibi kelimler kullanır (Strzelczyk, 2015).

Her birey belirli zaman içerisinde Ebeveyn, Yetişkin ya da Çocuk ego durumu sergileyebilmektedir. Bireyler değişen hazırlık sürelerinde bir benlik durumundan diğerine geçebilmektedir. Bu gözlemler belirli tanımlamalara neden olmaktadır. Örneğin; "Şimdi sen Ebeveyn (veya onların yerini tutan kişiler) gibi düşünüyorsun, onlardan biri gibi tepki gösteriyorsun, aynı duruş biçimini, tavırları, sözcükleri, duyguları vs. sergiliyorsun" biçiminde algılamak gerekmektedir. "Bu senin Yetişkin tutumun" demek ise "Şimdi sen içinde bulunduğumuz durumun bağımsız, nesnel değerlendirmesini yaptın; kendi oluşturduğun düşünce süreçlerini, algıladığın sorunları veya vardığın sonuçları belirli saplanmalara bağlı tavırlar almadan ortaya koyuyorsun" anlamına gelmektedir. "Bu senin Çocuk tutumun" demek ise "Gösterdiğin tepkinin amacı ve gösteriliş biçimi, küçük bir kız ya da erkek çocuğuyken ortaya koyduklarının aynısıdır” anlamına gelmektedir (Berne, 2001).

Yapısal modele ek olarak Bern, Şekil 2'de verilen duygusal deneyimlerinin ve anılarının içerik sırasına göre sınıflandırıldığ 1 ve sistematikleştirildiği ikinci düzey yapısal modeli de öne sürmüştür. $\mathrm{Bu}$ model, bireysel tarihsel ve bireyin kişisel gelişime yönelik daha derin bir anlayış sağlamaktadır (Johnsson, 2011). 


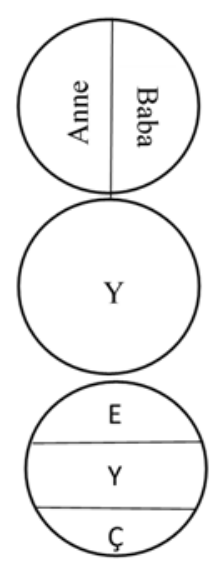

Şekil 2: İkinci Derece Yapısal Diyagram (Johnsson, 2011)

\subsubsection{2. İşlemsel Analiz}

İşlemsel analiz yaklaşımı (fonksiyonel analiz olarak da kullanılmaktadır), iletişim psikolojisini açıklayan yani süreçle ilgilenen kısmını oluşturmaktadır. Akbağ ve Deniz'e (2003) göre kişiler arası ilişkiler ve iletişim psikolojisi açısından bakıldığında ego durumlarının işlemsel analizde ele alınması daha doğru olabilir. Çünkü bu etkileşim halindeki bireylerin davranışlarıya ilgilenmemiz anlamına gelmektedir. Yapısal analizde kişiliğin yapısı irdeleniyorken işlemsel analizde kişiliğin farklı yanlarının işlevleri üzerine odaklanır. Daha açık bir ifadeyle işlemsel analizde hangi ego durumuyla nasıl eylemler sergilendiği öne çıkmaktadır (Torun, 2016).

İşlemsel analizde Ebeveyn ego durumu; Bakım Veren/Koruyucu Ebeveyn ve Eleştirel Ebeveyn; Çocuk ego durumu ise Uygulu Çocuk, Doğal Çocuk olmak üzere ikiye ayrılarak incelenebilmektedir (Solomon, 2003).

\subsection{Koruyucu Ebeveyn}

Koruyucu Ebeveyn duygusal destek sağlayan olumlama ve onaylama sunan ego durumudur. İlgili, affedici, şefkatlidir bununla birlikte endişelidir. Endişe nedeiyle zaman zaman aşırı korumacı olabilir. Toplumsal değerleri temel alır ve bunların dişına çıkıldığında zarar göreceğini düşünebilir. Bununla birlikte sağlıklı sınırlar çizebilme becerisine sahiptir. Bakım Veren Ebeveyn'in karşıdakine verdiği mesaj temelde “Sen OK'sin' dir (Akbağ ve Deniz, 2003; Solomon, 2003; Torun, 2015). 


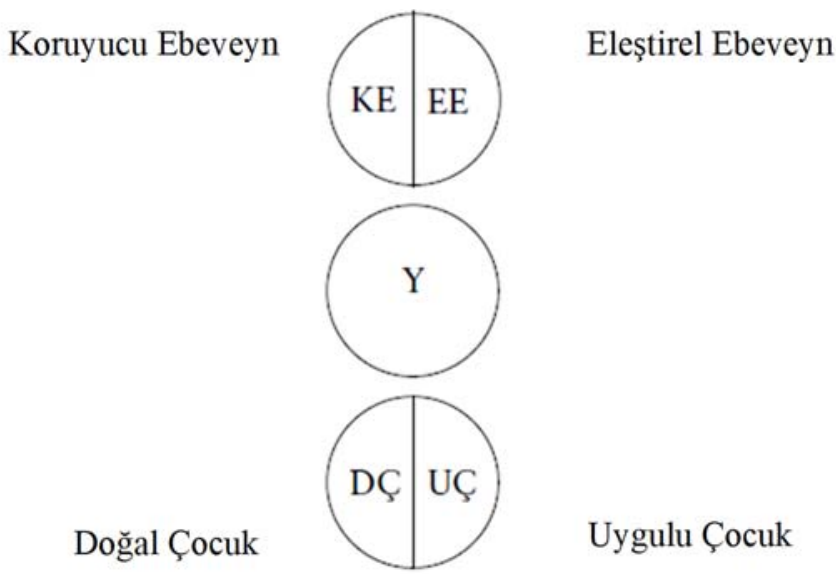

Şekil 5: Fonksiyonel Analiz Ego Durumları.

\subsection{Eleştirel Ebeveyn}

Ebeveyn ego durumunun bu yönü eleştirel, yargılayıc1, kural koyucu ve cesaret kırıcıdır (Seligman, 2010). Yetişkinlikteki önyargılı düşünce ve duygulara temel oluşturduğuna işaret edilmiştir (Solomon, 2003). Bireyler Eleştirel Ebeveyn ile hareket ettiğinde toplumsal normları, gelenekleri ve değerleri korumaya odaklanıp bunlara uymayanları katı şekilde eleştirmeye hatta cezalandırmaya yönelebilmektedir. Örneğin "Öyle oturulmaz", "Bir daha yalan söylersen fena yaparım” gibi mesajlar Eleştirel Ebeveyn Ego durumuna aittir (Y1lmaz, 2014).

\subsection{Doğal Çocuk}

Doğal ya da Özgür Çocuk, spontane duygu ve davranışların merkezidir. Dünyayı doğrudan ve anında deneyimleyen ego durumunu ifade eder (Solomon, 2003). Doğal çocuk fiziksel ihtiyaçlarını gözetir, otantiktir, içinden geldiği gibi davranır, hareketlidir aynı zamanda Yetişkin ile birlikte, yaratıcılığın da merkezidir (Solomon, 2003; Yılmaz, 2014). Bireylerin Doğal Çocuk yanlarıyla bağlantılı olması, samimi kişilerarası ilişkiler kurabilmelerinin de anahtarıdır. Doğal Çocukla daha temas halinde olmak hem duygusal iyi oluşu hem de kurulacak yakın ilişklerin sayısını azaltabilmektedir (Solomon, 2003).

\subsection{Uyumlu/Uygulu Çocuk.}

Uyumlu Çocuk, kişiliğin büyürken alınan ebeveyn mesajlarına uymayı öğrenen parçasıdır. Çocuğun anne babasının sevgisini ve onayını kaybetmemek için ortaya çıkmıştır. Uygulu çocuk sürekli gözlendiği ve dinlendiği hissine sahip olarak hareket eder diğer deyişle Doğal çocuğun sahip olduğu otantik tepkilerden yoksundur (Akkoyun, 2011; Solomon, 2003; Torun, 2015). Kavram olarak uyumlu, boyun eğen bir yapıyı çağrıştırsa da bazen kısıtlayıcı ebeveyn mesajlarına uymak yerine onlara isyan edebilir (Solomon, 2003). Buradaki önemli nokta ister ebeveyn komutlarına uysun isterse de isyan edip tam tersi davranışlar sergilesin Uygulu Çocuk, kendi gerçek istediğini değil, manipülasyonlara bir tepkisini ortaya koymaktadır. TA bireylerin yetişkin yaş dönemlerinde dahi otorite figürleriyle başa çıkarken seçtikleri davranışların Çocuk ego durumuyla bağlantılı olabileceğini öne sürmektedir (Aydın, 2015). 
Her insan bağımsız ve eşsiz bir kişiliğe sahip olduğu için ego durumlarının beş boyut Eleştirel Ebeveyn, Koruyucu Ebeveyn, Yetişkin, Doğal Çocuk, Uygulu Çocuk her bireyde farklı oranlarda ve dengede yer almaktadır (Alisinanoğlu ve Köksal, 2000).

\subsubsection{Egogram ve Sabitlik Hipotezi}

TA'da kişilik yapısını oluşturan Ebeveyn, Yetişkin, Çocuk ego durumları birbirine değen üç daire ile ifade edilmekle birlikte barındırdıkları enerjinin miktarı egogramla sembolize edilmektedir (Yılmaz, 2014). Egogram; Eleştirel Ebeveyn (EE), Koruyucu Ebeveyn (KE), Yetişkin (Y), Doğal Çocuk (DÇ), Uygulu Çocuk (UÇ) sırası ile olmak üzere, göreceli olarak bir kimsenin başkalarıyla ilişki kurarken sarf ettiği gözlenen enerjinin grafiksel gösterimidir (Akkoyun, 1995).

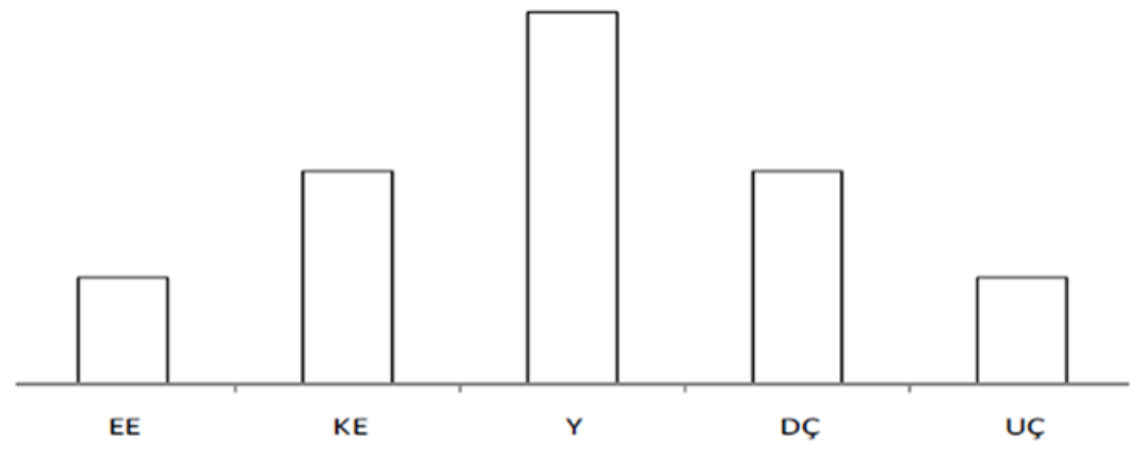

Şekil 6: Egogram Örneği (Keler, 2008).

Grafikteki yüksek değerler nispeten yaşanan anda aktif olan ego durumunda daha fazla zaman ve enerji harcandığını yansıtırken düşük değerler için ise tam tersi geçerli olmaktadır. Daha açık bir ifadeyle bir ego durumunda diğerine göre daha fazla enerji harcanması, o ego durumunun daha sık kullanılma olasılığına işaret etmektedir (Beycan Ekitli, 2013). Ayrıca, egogram temelde ego durumları bağlamında sabitlik hipotezini yansıtmaktadır. Bu hipotez tıpkı Psikanalitik yaklaşımdaki gibi psişik enerjinin sabit ve dengede olduğunu ve bir ego durumundaki enerjide artış olduğunda enerjinin yer değiştirmesiyle diğer ego durumlarındaki enerjide bir azalmanın olacağını öne sürmektedir (Keler, 2008). Bu tepki vermede esnekliği de yansıtan bir özelliktir. Nitekim TA'ya göre, insanlar sürekli olarak bu ego durumlarından birinden diğerine kaymaktadır ve herhangi bir zamanda davranışları şu anda bulundukları ego durumuyla ilgilidir. İnsanlar en fazla enerjiye sahip olan ego durumundan çalışırlar ve o ego durumundan kararlar alırlar (Corey, 2016).

\subsubsection{Temas İletileri (Dokunulma/Tanınma Açlığı)}

Temas iletisi, bireylerin varlığının onandığını gösteren ve duyumlarına hitap eden tüm mesajlardır (Akkoyun, 2011; Sevim, 1996). Bebeklik yıllarında dokunulma ile başlayıp, yetişkinlikte fark edilme ihtiyacıyla da devam etmektedir (Çatak, 2012). Dokunmanın insanlar üzerindeki yaşamsal değerini gözleyen Berne, bunun temelde 'varlığın onanması, tanınması' ihtiyacını karşıladığını belirtmiştir. Anne ile başlayan okşama/dokunma toplumsal eylemin temel birimi olarak alışveriş-karşılıklı bir davranış (transaction) oluşturur (Berne, 2001). Bir temas iletisini bakış, baş sallama, gülümseme, söz veya 
dokunuş gibi bireyin varlığını geçerli kılmayı sağlayan herhangi bir mesaj olarak olabilmektedir (Solomon, 2003).

Temas iletileri, dışsal kaynaklı; çevreden ve başka insanlardan alınan veya içsel kaynaklı; kişinin kendisinden kaynak alan iletiler olabilir. Ayrıca olumlu, olumsuz, koşullu ve koşulsuz da olabilir. Kişinin kendisiyle olan iletişimi, düşünceleri, anıları, hayal dünyası, o anda çevresinde başka insanlar olmasa bile birer temas iletisi olarak işlev görebilir (Solomon, 2003; Yönder, 2012).

\subsubsection{Zamanı Yapılandırma}

Kucaklanma ve tanınma isteğinden sonra Berne (2001) düzenleme isteğinin geldiğini belirtmiştir. İnsanlar temas iletisi ihtiyaçlarını zamanı farklı şekillerde yapılandırarak düzenlemeye çalışmaktadır. TA kuramında bireyin diğer bireylerle olan ilişkisinde geri çekilme, ritüel/tören, vakit geçirme, aktivite/etkinlik, psikolojik oyunlar ve içtenlik/samimiyet olmak üzere altı şekilde zamanı yapılandırma biçimi yer almaktadır (Çatak, 2012). "Geri çekilme” bireyin çevresiyle ve başkalarıyla iletişimini kestiği, "ritüeller" sosyal normların hayata kazandırdığı davranış kalıpları, "vakit geçirme" sosyal yasamdaki eğlentilikleri, "etkinlik" sosyal yasamda kendini ortaya koyma davranışlarını, psikolojik oyunlar" gizil mesajlarla gerçekleştirilen etkileşimleri, son olarak "samimiyet" ise, bireylerin birbirlerine karsı duygularını maskelemeksizin ifade etmelerini yansıtmaktadır (Özerk, 2008).

\subsubsection{Yașam Pozisyonları}

TA, tümü çocukluk deneyimleri sonucunda alınan kararlara dayanan ve insanların kendileri hakkında nasıl hissettiklerini ve başkalarıyla nasıl ilişki kurduklarını belirleyen dört temel yaşam pozisyonunu tanımıştır (Corey, 2016). Berne (1972) bu pozisyonların evrensel olduğunu ve bireylerin bu pozisyonların her birine sahip olsa da birinin baskın olduğunu öne sürmüştür (Johnsson, 2011). Harris (2017) dört yaşam pozisyonu aşağıdaki gibi açıklamıştır:

Ben OKEY değilim, Sen OKEY'sin: Bu pozisyon, doğum ve bebeklik durumunun getirdiği kendini güçsüz, zayıf, temasa ve bakıma muhtaç algılayan diğerlerini ise güçlü ve kontrol sahibi olarak gören çocuk için mantıklı bir sonuçtur ve erken çocukluğun evrensel pozisyonudur (Seligman, 2010; Harris, 2017). Harris'e (2017) göre, çocuklar yaşamın en erken çağında "Ben OKEY değilim, Sen OKEY'sin" sonucuna ulaşırlar. Bu pozisyonda "iyi olmak" vardır çünkü temas mevcuttur. "İyi olmamak" çocuğun kendisi ile ilgili olarak yaptığı çıkarımın bir sonucudur ve en erken karardır. İkinci yılın sonunda bu karar teyit edilir böylelikle ya diğer kararlara dönüş sağlanır ya da bu pozisyon sabit kalır. Yaşam pozisyonu bir kez kesinleştiğinde sürekliliğini korur ve yaşam da bu pozisyona göre şekillenir.

Ben OKEY değilim, Sen OKEY değilsin: Bu pozisyondaki çocuklar tipik olarak temastan yoksun kalmış ve umutsuzdur (Seligman, 2010). Kendisinin "iyi olmadığını" düşünen çocuk, devam eden cezalandırmalar ve yaşadığı örselenmeler sonucunda "diğer insanların" da "iyi olmadıklarına" karar verir (Torun, 2015). Bu pozisyondaki kişiler yaşamdaki ilgilerini kaybetmiş durumdadırlar ve hayatı genel anlamda umutsuz olarak görürler (Karababa ve Dilmaç, 2016).

Ben OKEY'im, Sen OKEY değilsin: Ebeveynleri tarafindan uzun süre kötü muameleye maruz kalan çocuk pozisyonunu daha kriminal olan "Ben OKEY'im, Sen OKEY değilsin"e çevirir. Erken dönem öyküsünde istismar, taciz gibi travmalar olan bireylerin bu pozisyonda olduğu düşünülmektedir. 
Çocuk yaşadığı bu acılar ile "eğer beni yalnız bırakırsanız ben iyi olacağım, ben kendimle OK'im" anlamını oluşturur. Bu Harris (2017)’e göre bir tür hayatta kalma tepkisidir.

Ben OKEY'im, Sen OKEY'sin: Bern'in kısaltmasıyla TA teorisi ve felsefesinin temeli, insanın temel değerine ilişkin imgesi olan "OK" olmadır. Bu kavram, kişinin tüm davranışlarını onaylamakla karıştırılmamasına rağmen, insana değer vermeyi ve sayg1 duymayı içerir (Clarkson, 1993b). Yaşamlarının erken dönemlerinde kendileri ve diğerlerinin değerli olduğuna inana çocuklar bu pozisyondadır. İlk üç pozisyon yaşamın erken dönemlerinde dil gelişiminden önce alınan bilinçsiz kararlar iken son pozisyon bilinçli bir karardan oluşur. Her ne kadar bu pozisyonları doğuran erken deneyimler silinmese de bir karar oldukları için üzerinde er ya da geç seçim şansı bulunmaktadır. (Harris, 2017).

Sahip olunan pozisyon bireyin davranışını şekillendirir. Örneğin: diğer üç pozisyondaki bireylerin “neden” üzerinde durmaların karşın Ben OKEY'im-Sen OKEY'sin pozisyonu “neden olmasın” üzerinde durur (Harris, 2017). Yaşam pozisyonun kararı, kişinin "yaşam senaryosu" kararlarına da zemin hazırlamaktadır. Transaksiyonel Analiz yaşam senaryosunu kişinin bilinçdışı bir yaşam planı olarak değerlendirir (Torun, 2015).

\subsubsection{Yaşam Senaryosu}

Yaşam senaryosu, erken çocukluk döneminde şekillenen çocuğun kendisine, yaşama ve diğerlerine yönelik verdiği kararlara dayanan bilinçsiz bir yaşam planıdır (Harris, 2017; Solomon, 2003). Senaryonun oluşmasında en önemli etken ise bakım verenlerin farkında olmadan Çocuk ego durumlarına ilettikleri "yasaklar" ve "izinler" olarak betimlenen mesajlarıdır (Gökçen, 2009; Torun, 2015). Bu kararlar çocukken yaşamda kalma ve başa çıkma için oldukça mantıklıyken yetişkin dönemde işlevsel olmamakla birlikte uyumu zorlaştırıcıdır. Ancak erken kararlara ilişkin farkındalık oluşmadıkça bu kararların doğruluğunu kanıtlayan kalıplar bir döngü içinde sürekli tekrarlanır (Solomon, 2003). Örneğin kişi kendi senaryosuna bakarak başkalarının ona sırt çevirebilir böylece Ben OK Değilim'i doğrulayacağ 1 davranışlar içine yönelebilir (Harris, 2017). Bu bakımdan senaryo kavramı Bilişsel Terapi'deki "Şema" kavramı ile oldukça benzer niteliklere sahiptir (Johnsson, 2011).

\subsubsection{Komutları/Yasaklar ve Sürdürücüler ile Çocukluk Kararları}

Erken kararlar yaşam senaryolarının en önemli parçasıdır. Çocuklar bakım verenlerden nasıl düşünmesi, hissetmesi ve davranması gerektiği konusunda doğrudan ve dolaylı olarak belirli mesajlar (komut ve karşıt komutlar) almaktadır. Büyüdükçe sosyal çevreye eklenen aile büyükleri, öğretmenler gibi önemli yakın çevreden mesajlar almaya devam etmektedir (Solomon, 2003). Bu mesajları kendi bilişsel çerçevesinde nasıl konumlandırdığı kritik noktadır. Nitekim alınacak kararlar bu meajlara yanıt olarak çevreye en iyi uyumu sağlamayı amaçlayacaktır.

Yasak ya da komut, çocuklara yaşamlarını sürdürmek, kabul edilmek ve tanınmak için ne yapmaları gerektiğini söyleyen ebeveyn mesajları (sözel ya da davranışsal) olarak tanımlanır. TA'ya göre çocuk, yaşam hakkında öğrendiği yasakları temel olarak erken yaşta belli kararlar vermektedir. $\mathrm{Bu}$ erken öğrenmelerin birçoğu öğretildiği şartlara uygun olmasına rağmen yetişkinliğe taşındığında ve farklı durumlara uygulandığında genellikle yetersiz kalmaktadır (Hackner ve Cormier, 2008).

Goulding ve Goulding (1976) tekrarlı olarak verilen negatif bilişsel mesajların hafızada komutlar olarak saklandığını belirtmişlerdir ve genel olarak rastlanan 12 komut betimlemişlerdir: 1. Varolma, 2. 
Kendin olma, 3. Çocuk olma, 4. Büyüme, 5. Başarma, 6. Yapma, 7. Önemli olma, 8. Ait olma, 9. Yakın olma, 10. İyi / aklı başında olma, 11. Hissetme ve 12. Düşünme. "Kendin Olma!" yasağına bir örnek, hep erkek çocuk istemiş bir babanın doğan kız çocuğuna bilerek veya bilmeyerek erkek çocuk istediğine dair mesajlar iletmesi olabilir. Baba kız çocuğuna aldığı erkek oyuncakları hatta erkek giysileriyle, kızının sergilediği erkeksi davranışları desteklemesiyle kızına "Senin kız olmanı istemiyorum" mesajı verir: Kız olma! yani, "Kendin olma! Baba bu davranışlarıya kız çocuğunun kadın cinsel kimliğini gerçekleştirmesini adeta yasak hale getirmektedir (Gökçen, 2009).

\subsubsection{Psikolojik Oyunlar}

TA'ya göre başarılı ya da başarısız insanlar tarafından en çok paylaşılan pozisyon "Ben OKEY değilim, Sen OKEY'sin" pozisyonudur ve bununla başa çıkabilmek için en çok kullanılan yol da psikolojik oyunlar oynamaktır (Harris, 2017). Berne (2001) oyun kavramını "önceden sezilebilecek bir sonuca doğru gelişen tamamlayıcı, gizli karşl1ıklı davranış/transaksiyon dizileri” olarak tanımlamıştır. Oyunlar sürekli kendini tekrar eden yüzeysel, örtülü motivasyonlara daha doğrusu hileli yönlere sahip bir grup eylem olarak da düşünülebilir (Harris, 2017). Nitekim Bern daha sonra kavramın tanımına, Freud'un tekrarlama zorunluluğu kavramının bir varyasyonunu yansıtan "tekrarlanma" özelliğini de eklemiştir. Çünkü psikolojik oyunlar çok sayıda tekrarlanabilir işlem dizisinin bireyin çocukluk kalıplarını ve senaryosunu doğrulayıp güçlendirmekte ve oyunların sonuçları olumsuz duygulara yol açsa bile, tanınma ihtiyacını karşılamaktır (Johnsson, 2011). Sözü edilen olumsuz duygular ise çoğunlukla bireyin Raket duyguları olmaktadır.

\subsubsection{Raket Duygular}

Transaksiyonlarda oynan çeşitli oyunlar, raket duyguların hem bir parçası hem de raket duyguların deneyimlenmesiyle sonuçlanmaktadır (Stewart, 1996). Bununla birlikte Raket duygular genellikle kişilerarası Oyunlarda ortaya çıkan sonuçlarla ilişkilendirilse de bunlar Senaryo bağlantılı bir psikolojik sürecin bir ifadesi olarak da görülebilmektedir (Johnsson, 2011). Oyunlar ve raketler, insanların yaşam senaryosu kararlarını geliştirmek için oluşturdukları duygusal ve ilişkisel kalıplar olarak düşünülebilir (Tudor ve Hobbes, 2007).

Raketler genellikle çocuğun ebeveynlerinin izin vermediği duyguların yerini alan vekil duygulardır (Corey, 2016). Erken çocukluk döneminde fark edilen önemli bir diğer şey ailede belirli duyguların teşvik edilip diğerlerinin ise yasaklanmasıdır. Bireyler gelişirken otantik duygularını bu teşvik edilen diğer bir deyişle izin verilen duygularla örter. Bu asıl duyguların yerine geçen duygulara "raket duygular" denilmektedir. TA'da otantik duygular: öfke, üzüntü, korku ve mutluluktur. Ancak bunlar her zaman otantik duygular değildir; raket öfke, korku ve mutluluk olarak hissedilebilir.

\subsubsection{Transaksiyonlar}

Berne (2015) transaksiyonu, "sosyal ilişkinin temel birimi" olarak tanımlamıştır. Transaksiyon iki kişinin karşılıklı olarak belli ego durumları arasında gerçekleşen iletişim biçimidir (Akkoyun, 2011; Yönder, 2012). Daha açık bir ifadeyle, transksiyonlar temelde iletinin hangi ego durumundan hangi ego durumuna gönderildiğini yansıtmaktadır (Solomon, 2003). Bu gönderici ve alıcı etkileşimine dair tarnsaksiyonları Bern (1996), tamamlayıcı, kapalı ve gizil olmak üzere üç boyutta sınıflamıştır. 
1) Tamamlayıcı Transaksiyon: Etkileşimde olan kişilerden iletişimi başlatanın belli bir ego durumundan karşısındaki kişinin belli bir ego durumuna ileti gönderdiği ve hedeflediği ego durumundan tepki aldığı transaksiyon türüdür (Örnekler için bkz. Bern, 1996; Kaçar, 2008).

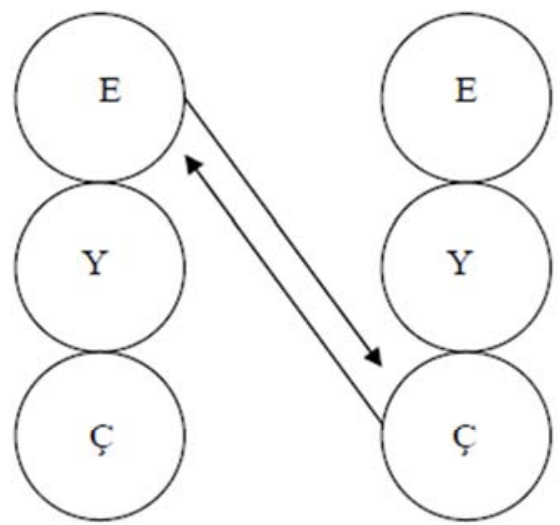

A

A: (Sert bir ses tonu ve kaşlar çatık)

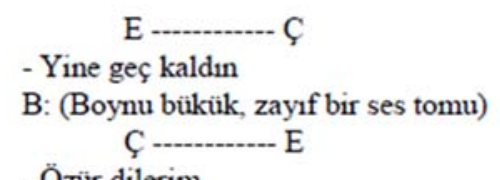

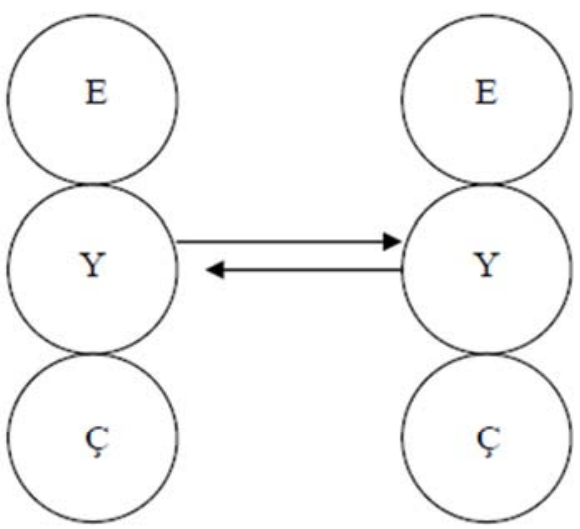

$\mathrm{C}$

$\mathrm{D}$

C: (Sakin bir ses tonu, Gözlerde merak ifadesi, nötr bir yüz ifadesi)

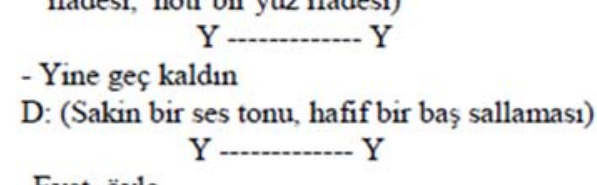

- Evet, öyle

Şekil 7. Tamamlayıcı Transaksiyon Örnekleri (Kaçar, 2008).

Tamamlayıcı transaksiyonların açık, net ve ödüllendirici etkileşimlere ve ilişkilere yol açması muhtemeldir. Çünkü insanlar ifade etmek istediklerini iletirler ve diğer bireyin ne dediğini anlayabilirler. Bu olası anlaşmazlıklara karşı çözüme açık bir etkileşim yaratır (Seligman, 2010). Nitekim iletişimin birinci kuralına göre: Transaksiyonlar tamamlayıcı olduğu sürece, iletişim sonsuza kadar sürebilir (Özerk, 2008; Harris, 2017).

2) Kapalı Transaksiyon: İletişimdeki kişilerin belli bir ego durumundan ileti gönderirken karşısındaki kişiden hedeflediği ya da beklediği ego durumundan karşılık alamadığı transaksiyon türüdür (Örnekler için bkz. Bern, 1996; Kaçar, 2008). Ayrıca bu transaksiyon türüne çapraz transaksiyon adı da verilmektedir (Harris, 2017). Bern (1996) bu kapalı transaksiyonların evlilik, meslaki ve sosyal yaşamda genellikle yanlış anlamalarla yol açtığını belirtmiştir. 


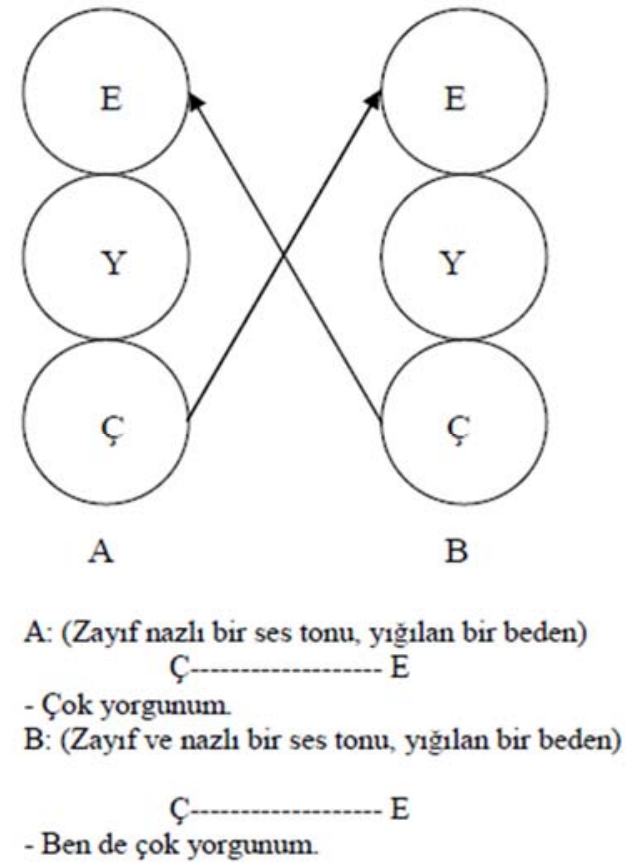

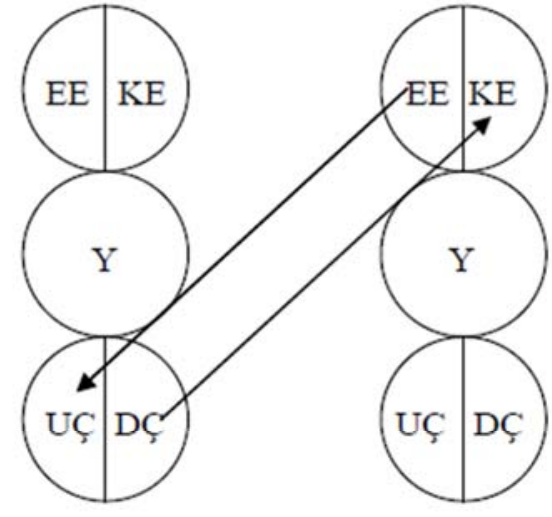

$\mathrm{C}$

$\mathrm{D}$

A: (Zayıf nazlı bir ses tonu, yığılan bir beden) $\mathrm{DC}$ - KE

- Cok yorgunum.

B: (Sert bir ses tonu, bedeni karşısındakinin aksi yönüne çeverme)

- Ne yapayım?

Şekil 8. Kapalı Transaksiyon Örnekleri (Kaçar, 2008).

İletişimin ikinci kuralı: Kapalı transaksiyonlarla, iletişimde olan kişilerden en az biri kendi ego durumunu değiştirip yeniden iletişim kurma çabasına girmezse iletişim devam etmeyebilir (Özerk, 2008; Tüfekçi, 2008).

3) Gizil Transaksiyon: İletişimde bulunan iki kişiden birinin ya da her ikisinin birden fazla ego durumlarından ileti gönderdiği ancak aynı anda hem açık olarak sosyal düzeyi hem de örtük mesaj olarak psikolojik düzeyi barındıran iki farklı mesajın birlikte yer aldığı transaksiyon türüdür (Örnekler için bkz. Bern, 1996; Kaçar, 2008). Görünüşte tamamlayıcı transaksiyona benzer fakat görülen iletinin altında başka bir ego durumunun iletisini taşıyan gizli bir anlam bulunmaktadır (Harris, 2017; Akkoyun, 1995). Gizil transaksiyonlar örneklendirilirken sosyal mesajlar düz çizgi, psikolojik mesajlar ise kesik çizgi ile belirtilmektedir (Bkz. Şekil 9): 


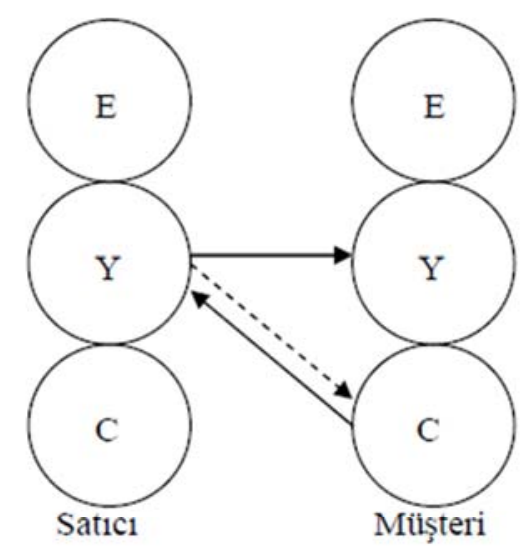

Satıcı: (Gözler kısık, ağzı yana doğru bükük, iğneleyici bir ses tonu) Sosyal Düzeyde: Y

- Bu en iyi malımız ama çok pahalı

Psikolojik Dizeyde: E-_................

- "Sen bunu alamazsin"

Müşteri: (Gergin bir yüz, seri el-kol hareketleri)

Sosyal Düzeyde: Ç-.-.-.-.-...-Y

- Tamam aliyorum

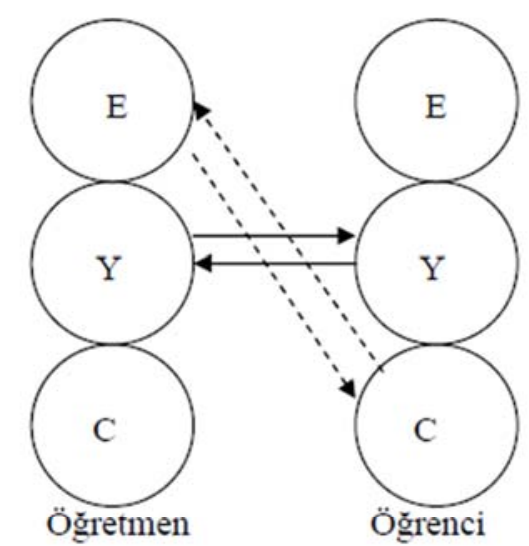

Ögretmen: (Sert bir ses tonu, cümlenin sonunda ses tonunda düşüuş, çatık kaşlar) Sosyal Düzeyde: Y.................................

- Ödevini yaptın m?

Psikolojik Duizeyde: E-

- "Yine yapmadin değil mi?"

Ögrenci: (Titrek bir ses tonu, bașı yana eğme, omuzlarda çökme.)

Sosyal Dizeyde: Y.................................

- Evet yaptim.

Psikolojik Düzeyde: E

- "Benden hiç hoşlanmiyorsun."

Şekil 9: Gizli Transaksiyon Örnekleri (Kaçar, 2008).

İletişimin üçüncü kuralı: Gizil transaksiyonun ardından ortaya çıkacak olan davranışı belirleyen psikolojik düzeydeki mesajdır (Özerk, 2008; Tüfekçi, 2008).

\subsection{Transaksiyonel Analiz’in Psikopatalojiye Bakışı}

TA'nın sağlık ve sağlıksızlık kavramsallaştırmaları Tudor ve Hobbes (2007)'a göre 4 teorik temeli yansıtır: Ego Durumları, Transaksiyonlar, Senaryolar ve Oyunlar. TA'ya göre psikolojik sağlık esnekliği ve şimdi ve burada odaklı olmayla vurgulanan Yetişkin ego durumu olarak düşünülebilir. TA'ya göre sağlıklı bir kişilik için her bir ego durumunun da katkısı gerekmekle birlikte tepki ve davranışlarının kontrolünün Yetişkin ego durumunda olması elzemdir (Buluş ve Atan, 2016). Bu şekilde düşünüldüğünde sağlıklı birey, diğer insanlara karşı iyi bir ebeveynin özellikleri olan dürüst ilgi ve kararlara, bir yetişkin özelliği olan problem çözme akılcıllğına bununla birlikte mutlu ve sağlıklı bir çocuğun özellikleri olan yaratıcılık, merak ve sevecenlik gibi özelliklere sahiptir. Nitekim TA'da bu Bütünleşmiş Yetişkin olarak ifade edilmektedir (Akbağ ve Deniz, 2003).

TA yaklaşımında patolojinin açıklanması benlik durumları üzerinden tanımlanmaktadır. İdeal olarak, üç ego durumu bireyin kişiliğinde bir denge halindedir. Ancak kişi belli bir ya da iki ego durumuna katı şekilde bağlıysa veya bir ego durumu diğerine bulaşıyorsa veya iç içe geçiyorsa bu başta ilişkilere zarar vermekle birlikte çeşitli sorunlara yol açabilir (Seligman, 2010). Bu doğrultuda sağlıksızlığı açıklayan iki işlevsel problem: "Bulaşma/Birbirine Geçme” ve "Dışlama"dır (Harris, 2017; Aydın, 2015). Ego durumları için dışlanmaya (exclusion) örnek vermek gerekirse (Aydın, 2015); Ebeveyn benlik durumu dışlandığında bireyler kendi içinde tutarlı ilke, değer ve kurallara yönelik değil 
o anki algılarına yönelik reaktif davranmayı seçerler. Dolayısıyla sınırda kişilik bozukluğu TA'ya göre bu şekilde tanımlanır. Benzer şekilde eğer Yetişkin ego dışlanmışsa kişi gerçeği test etmekte sorun yaşayacak ve arkaik benlik durumları olan Çocuk ve Ebeveyn diyalogları arasında sıkışacaktır. Bu durum psikoza kadar varan patolojik sorunlara yol açabilir (Aydın, 2015).

Bir diğer psikopatoloji bulaşma/birbirine geçme (contamination)'dir. Bu devamlı şekilde bireyin bilinçli farkındalığın dışında diğer benlik durumlarının Yetişkin'e müdahale etmesidir (Aydın, 2015). Harris (2017) Ebeveyn'in Yetişkin'e bulaşmasına ön yarg1, Çocuk'un Yetişkin'e bulaşmasına da hezeyanlar ve halüsinasyonlarla tanımlamıştır. Daha önce de değinildiği gibi arkaik benlik durumlarının bilinçsiz yaşantıları ve kararları Yetişkin tarafindan değerlendirilip güncelleştirilmelidir. Bu bakımdan tedavi bu bulaşan benlik durumlarının ayrılması ve sınırlarının tekrar çizilmesi olarak görülebilir (Harris, 2017).

\subsection{Terapötik Amaçlar}

Transaksiyonel Analiz Terapisinin öncelikli amacı anlamlı kişiler arası ilişkiler kurmak ve geliştirmektir (Tudor ve Hobbes, 2007). TA'da danışanlara hayatları ve terapideki ilerlemeleri için sorumluluk almaları için yardım edilir. İlişkisel sorunlar terapinin en önemli çalışma alanı olma eğilimindedir; bu bakımdan danışanın geçmişinin diğer insanlarla ve/veya terapistle şimdi ve burada ilişkisini nasıl bozduğunu incelemek odak noktasıdır (Clarkson, 1993b). Terapide iki ana amacın olduğuna dikkat çekilmiştir: (i) özerk Yetişkin egoyu güçlendirmek ve (ii) ben Ok'im, sen OK'sin yaşam pozisyonuna ulaşabilmektir (Widdowson, 2016).

Harris (2017) TA'nın aslında bir öğrenme deneyimi olduğunu ve bu deneyim boyunca danışanların kararlarına işlemiş olan bilgiyi nasıl çözümleyeceğini keşfettiklerini belirtmiştir. $\mathrm{Bu}$ bakımdan, her insanı kendi transaksiyonlarını analiz eden bir uzman haline getirmeye yardım etmek önemlidir. Böylece danışanın Yetişkin'i özgürleşecek geçmişin sınırlayıcı etkisi olmaksızın özgür iradeyi ve yeni seçeneklerin oluşmasını deneyimleyebilecektir. Nihai amaç Yetişkin'i güçlendirmek, özgür ve özerk kılmaktır. Yani terapi bilinçdışı konusunda değil ama özerklik konusunda içgörü kazanmanının önemini vurgulamaktadır. Berne (1964)'e göre bunlar farkındalık, spontanlık ve yakınlık/samimiyetten oluşur (Seligman, 2010). Yetişkin'i güçlendirmek için yapılacak başlıca şey ise bireyin Ebeveyn ve Çocuk'un sinyallerine karşı daha duyarlı hale gelmesine yardım etmektir (Harris, 2017). Ayrıca bu yolla bireyi arkaik ve otomatik hale gelmiş tepkilerini kontrol edebilir şekilde güçlendirmek de önemlidir. Bu bireylerin içindeki OK olmama pozisyona ve Ebeveyn sinyallerine duyarlı, onları reddetmeksizin farkında olma ve kabul etmek anlamına gelir.

Terapist süreçte danışanla kurduğu kabule dayalı ve samimi ilişki kurmaya gayret etmektedir. Böylesi bir ilişki terapide ortak bir amacın varlığına işaret ettiği gibi ben OK'im sen OK'sin pozisyonu da danışana yansıtmaktadır. Yani OK olma pozsiyonuna dayalı ilişki Danışan Merkezli Terapi'nin temel terapötik koşullarından biri olan "koşulsuz kabul ve saygı" kavramı ile paraleldir (Widdowson, 2016).

Yaklaşımın temel ilkeleri ve kavramları düşünüldügünde ise süreçte ulaşılmaya çalışılan değişimler her bir danışanın: (i) kişiliği şekillendiren ego durumları arasındaki dengesi, (ii) diğerleriyle kurduğu transaksiyonların doğası, (iii) oynadığı psikolojik oyunlar ve raket duygular (fonksiyonel olmayan, manipülatif roller ve etkileşimler) (iv) yaşam pozisyonu ve (v) yaşam senaryosuna dair daha açık bir resme ulaşmasına yardımcı olmaktır. Bu bilgilerin anlaşılması ve analiz edilmesiyle bireyler, geliştirdikleri kalıpların daha fazla farkında olarak bunları daha sağlıklı olacak şekilde düzenleyebilir (Seligman, 2010). Nitekim böylesi bir farkındalık özerk ve özgür bir Yetişkin ego ile OK pozisyonuna yaklaşmalarını mümkün kılabilir. 


\subsection{Terapistin Rolü ve İşlevi}

TA terapisinde terapist, danışanın ihtiyaçlarını ile terapi süreci arasında uyum sağlayan esnek bir rol üstlenmektedir. Terapistin önemli bir işlevi danışanı sürecin aktif ve sorumluluk alan bir katılımcısı olmaya davet etmektir. Bu işlev, hümanist mirasının bir parçasıdır ve eşit değerlerde veya OK konumunda olan iki kişinin karşıllklılı ilişkisine dayanmaktadır (Clarkson, 1993b). Terapistin koşulsuz kabul ve saygıyı ileten diğer bir değişle ben OK'im sen OK'sin yaşam pozisyonunu yansıtan bir ortam inşa etmesi oldukça önemlidir (Widdowson, 2016). Ayrıca Berne, danışanların terapist kadar terapideki çalışmaların nası1 yürütüleceği hakkında bilgi sahibi olmaları gerektiği konusunda 1srarcı olmuştur. Bu ısrarı da TA yaklaşımının da varsayımlarından olan; insanların OK olduğu ve her insanın düşünme kapasitesine sahip olduğu varsayımlarına dayanmaktadır (Stewart, 1996). Danışan yapmak istediği değişimler konusunda hem söz sahibi olmalı hem de sorumluluk almalıdır. Değişim sürecinde danışan işbirlikçi bir partnerdir yani terapist ve danışan ortak paydaları ve sorumlukları paylaşırlar (Stewart, 1996, Seligman, 2010; Widdowson, 2016). Bu doğrultuda terapist ve danışan arasındaki iş birliği son derece önemlidir (Seligman, 2010).

TA, terapötik sürecin bilişsel ve davranışsal yönlerini vurgulamaktadır. Bu yönde TA terapisti danışanların çocukken uyum sağlayıcı olabilen ancak bugün geçerli, yararlı veya güçlendirici olmayan tersine kendini sabote edici olan erken kararlarını, mevcut koşullar ışığında yeniden düşünmelerine ve yeniden değerlendirmelerine yardımcı olmaya odaklanmaktadır (Corey, 2016). Terapi sürecinin başlangıcında mutlaka terapist ve danışan birlikte karar vererek danışanın istekleri doğrultusunda değiştirmek istediği noktalara odaklanan ortak bir kontrat oluşturmanın gerekliliği üzerinde durulur (Aydın, 2015). Kontratta terapinin doğası, danışanın ve terapistin rol ve sorumlukları açıklanır (Seligman, 2010). Harris (2017) ise terapi sürecinde terapistlerin danışanlarına TA’nın kavramları öğretmeleri ve benimsetmelerinin gerekli olduğu üzerinde durmuştur. Ardından danışan sunduğu sorun bu yeni dil kullanılarak açıklanacaktır. Bu aşamalardan sonra süreçte transaksiyonların incelenmesi, yaşam senaryosu, oynadığı oyunlar, yaşam öyküsü ve tüm bunlar bireyin mevcut sorunları ile karşılaştırılması ve ilişkisi değerlendirilir.

\subsection{Terapötik Teknik ve Yöntemler}

TA uygulayıcıları için terapötik ilişki istenilen sonuçların ortaya çıkması için tek başına yeterli değildir. Uygulayıcılar danışanın sorunları için analiz geliştirir ve yapacağı değişimleri içeren bir kontrat için karar verirler, ardından bu değişimler için aktif şekilde planlanmış ve yapılandırılmış müdahaleler kullanılırlar (Stewart, 1996). Genel olarak terapi yöntemleri, içgörüden çok şu andaki karar temelli davranış değişikliklerine odaklanır. Kişisel değişim, danışan ile terapist arasında karşılıklı olarak kabul edilen tedavi kontratının (sözleşmesinin) tamamlanmasıyla sağlanır (Johnson, 2011). En geniş çerçevede TA'nın sıkıntıyı hafifletmeyi, öz farkındalığı ve büyümeyi teşvik eden birçok teknik ve kişilerarası ilişkileri geliştirmek için de pek çok yöntem önermektedir (Clarkson, 1993b). Bununla birlikte Berne'den bu yana TA psikoterapinin gelişimiyle farklı ekollerden birçok tekniği de kendine uyarlamıştır (Tudor ve Hobbes, 2007).

TA'da kullanılan müdahaleleri pek çok araştırmacı farklı şekilde sınıflamıştır örneğin Johnson (2011): "arındırma, ayrıştırma ve yeniden karar verme" olarak müdahaleler üçe ayırmıştır. Arındırma danışanın Çocuk ve Ebeveyn Ego durumunun sağlıksız karışımından sıyrılarak şimdi ve burada odaklı Yetişkin ile çalışmaktır. Ayrıştırma, terapi Çocuk Ego durumundaki duygusal çatışmalara odaklanırken terapistin danışanı bütünleştirmeye çalıştığı müdahalelerdir. Yeniden karar ise Yaşam Senaryosunda özerkliğe ulaşmak için gereklidir ve buna yönelik müdahaleleri içerir. Bunlar erken çocukluk döneminde 
verilmiş yetişkin döneminde ise olumsuz duygu ve düşünce ve davranışlara yol açan kararları yeniden ele almaktır. Yeniden karar almak için yetişkinin farkındalık ve içgörü kazanması gereklidir. İkinci adım ise eski kararı alan çocuğa ulaşmaktır. Geştalt teknikleri, psikodrama ya da meditasyon, iletişim kurmak için kullanılabilecek tekniklerdir (Gültekin ve Voltan-Acar, 2004). Stewart $(1996,2013)$ ise TA'nın İnsanlar OK'dir, düşünebilir ve seçim yapabilir temel varsayımlarından hareketle "kontrat modeli" ve "açık iletişim" olarak iki uygulama tanımlamıştır.

TA yaklaşımında kontrat kullanılan temel tekniklerdendir. Danışanla yapılan kontrat onun duygu, düşünce ve davranış temelinde yapmak istediği değişiklikleri spesifik ve somut tanımlamayı amaçlamaktadır (Akbağ, 2013). Ayrıca kontrat terapinin doğası, danışanın ve terapistin rol ve sorumluklarını belirginleştirir (Seligman, 2010) ve pratikteki unsurları örneğin zaman, sıklık, ücret ve gizlilik gibi ele alır (Johnson, 2011). [Farklı nitelikteki kontrat türlerini incelemek için bkz. Rotondo, 2020].

TA yaklaşımının öne sürdüğü etkileşim kuramına göre terapi ve danışma süreci de dahil olmak üzere herhangi bir ilişkide taraflar birbirlerine gizil mesajlar gönderebilirler. Terapist ve danışan arasında da böyle bir durum söz konusu olabilir. Bu nedenle kontratın en önemli fonksiyonu kapalı mesajları açık hale getirmektir. Gizil mesajların açığa çıkarılmasıyla net bir kontratın yapılması süreç esnasında oynanabilecek psikolojik oyunları engelleyebilir (Akbağ, 2013). Kontrat, eğer terapist ya da danışan başlangıçtaki hedeflerden sapacak olursa gözden geçirilmelidir (Harris, 2017). Bu anlamda iyi yapılandırılmış bir kontratın bir diğer avantajı, terapi süreci boyunca her iki tarafa ne yaptıklarını ve nasıl ilerlediklerini değerlendirme şansı vererek, aylar hatta yıllarca sonu gelmezcesine aynı problem üzerinde çalışılmasına engel olmasıdır (Akbağ, 2013). Bir anlamda kontrat sürecin kontrolünü de sağlar (Gültekin ve Voltan-Acar, 2004). Lennox (1997) iyi bir kontratın aşağıda verilen üç temel soruya açıklık getirmesi gerektiğini belirtmiştir (Akt: Akbağ, 2013):

i. Yaşam kaliteni arttırmak için kendinle ilgili yapmak istediğin değişiklik nedir?

ii. Bu değişimi yerine getirdiğini (davranışsal olarak) sen ve ben nasıl bileceğiz?

iii. Farklı olarak ne yapacaksın veya nasıl hissedeceksin, değiştirmek istediğin şeyin yerine neyi koyacaksin?

TA yaklaşımında terapistin ana rolü danışanın ego durumlarına ve diğer bireylerle etkileşim içindeyken bu ego durumlarını nasıl kullandığına farkındalık kazandırmaktır (Harris, 2017; Tudor ve Hobbes, 2007). Bu doğrultuda terapist TA'nın anahtar kavramlarını danışana öğretmelidir. Böylece danışan oynadığı oyunları ve senaryosuna karşı da farkındalık geliştirecektir. Terapistler aktif/yaşantısal teknikleri örneğin Gestalt Terapi’nin çift sandalye tekniği gibi teknikleri de kullanabilirler. Bu ego durumları arasındaki içsel diyaloğa karşı farkındalı̆̆ artırır (Tudor ve Hobbes, 2007).

Özetle TA'nın temel teknikleri: her danışma aşaması öncesi kontrat yapma, danışana EbeveynYetişkin-Çocuk ego durumları dilini öğretme, yaşam senaryosu analizi, yapısal ve fonksiyonel analiz, oyunların analizi, komutlar ve yeniden karar verme çalışmaları, soru listeleri kullanma, yüzleştirme rol yapma, çift sandalye tekniği, psikodrama ve meditasyondur. Bunlara ek olarak oturumlar kasete alınmaktadır (İkiz, 2016; Gültekin ve Voltan-Acar, 2004; Hackney ve Cormier, 2008).

\subsection{1. Örnek Teknik: Komutlar ve Yeniden Karar Verme Çalışmaları}

Komutlar ve Yeniden Karar Verme Çalışmaları TA'da yer alan bilişsel bir müdahaledir. Tekniğin amacı, danışanın çocukken benimsediği belirli komutların daha çok farkında olması, bir yetişkin olarak 
komutların etkisini yeniden incelemesi ve ardından bu komutlara göre yaşamaya devam edip etmeyeceğine karar vermesi veya yeni kararlar almasına yardımcı olmadır. Bu müdahale, mevcut davranışı birçok durum için uygun olmayan ve sanki kafasında bir kaset varmış gibi hala işittiği ebeveyn türü bir veya iki mesaja bağlı görünen danışanlarla çalışırken özellikle yararlı olabilir. Uygulamada komutlara eşlik eden inanç ve düşüncelere ayrıca dikkat edilir. Daha sonra bu komutlar yeni bir kararı desteklemek için ihtiyaç duyulan yeni inanç ve düşüncelerle değiş̧irilir. Sırasıyla şu adımlar izlenebilir (Hackney ve Cormier, 2008):

a) Büyürken örneğin dört ile sekiz yaşların arasında annenin olumsuz veya kötü bir sesle sana söylediği şeyler duyduğunu hatırlıyor musun?

b) Şimdi de babanın sana olumsuz veya kötü bir sesle sana söylediği şeyleri hatırlar mısın?

c) Büyürken evinizde aşağıdaki listede verilen komutlardan sık bir şekilde kullanılan iki veya üçünü belirler misin? (Bu liste yukarıda 12 maddeden oluşan ele alınmış komutlardır.)

d) $\mathrm{Bu}$ komutlardan birini seç ve bu komuta dayalı olarak yaşamında verdiğin birkaç kararı hatırlamaya çalışır mısın? Bunun hakkında konuşabilir veya yazabilirsin.

e) Bu kararla ilgili sende oluşan düşünceler nelerdir? Onlar gerçek mi? Nasıl hissettiğini ve davrandığını etkiler mi?

f) Bu kararın şimdi senin için uygun olup olmadığ 1 hakkında ne düşünüyorsun? Eğer uygun değilse şu ana uygun karar ne olabilir? Bunu yazabilir misin? Yazarken bunun davranışlarına nasıl yansıyacağını da belirtmelisin. Bu kararla kendini nasıl hissedeceksin?

g) Yeni kararını uygulamaya geçmeden önce sen bir plan geliştirmene sana yardımcı olamaya çalışacağım. Bu planı ne bozabilir? Planını hangi düşünceler zayıflatabilir? Planını desteklemek için ihtiyaç duyduğun düşünceler nelerdir?

\subsection{Terapinin Değerlendirmesi}

\subsection{1.Çok Kültürlüllük Açısından Değerlendirilmesi}

TA yaklaşımı pek çok kavramı içeren oldukça geniş kapsamlı bir yaklaşımdır. Yaklaşım her insanın kendine özgü bir yaşam senaryosu olduğunu öne sürmesi bakımından her bireyin biricik olduğunu öne çıkarmaktadır. Bu bakımından farklı pek çok kültürel özelliklere sahip bireylerle çalışmaya uygun bir yaklaşımdır. Yaklaşımda yer alan her insan OK'dir, herkesin düşünme kapasitesi vardır, yaşamında ne olacağına herkes kendisi karar verir ve seçim yapabilir şeklindeki temel ilkeleri, tüm insanlara olumlu bakış açısını yansıtmakta ve hangi kültürden ya da aileden gelirse gelsin yeterli ve değerli görüldüğünü vurgulamaktadır. Danışanla kurulan eşit ilişki ve bir terapi kontratı geliştirme, danışanla güç farklılığını ortadan kaldıran ve danışanı güçlendiren bir yaklaşımdır. Kontrat ya da diğer yaklaşımlarda kullanılan şekliyle terapi sözleşmesi özellikle kültürel olarak dezavantajlı konumda bulunan bir grup olan kadınlarla çalışırken Feminist Terapide de çok fazla yaralanılan tekniklerden biridir (Murdock, 2016). Bunlara ek olarak terapiden direkt-doğrudan ve eğitimsel bir beklentiye sahip olan bireyler için TA uygun bir yöntem olabilir çünkü pratik becerileri önemi vurgulanmaktadır. TA kültürler arası kullanıldığında da çoğu yöntem genellikle aynıdır, Ego durumları gibi pek çok kavram birçok kültürde kolayca anlaşılabilir (Corey, 2016). 
Çok kültürlü uygulamalar bakımından güçlü olan yanlarına karşın sınırlı olduğu pek çok nokta da bulunmaktadır. TA’nın önemli kavramları ve terapinin amaçları göz önüne alındığında kültürel duyarlığa uyunluğu bakımından eleştiriler yapmak mümkündür. Örneğin önemli bir eleştiri Mazzetti (2010a) tarafından yapılmıştır. Aktardığına göre Bern (1972/1996) kültürün yaşam senaryoları üzerinde çok fazla etkisi olmadığını ifade etmiştir, buna katılmayan Mazzetti, kültürün yaşam senaryoları üzerinde güçlü bir etkisi olduğunu vurgulamıştır. Nitekim Mazzetti'ye katılmamak mümkün değildir. TA'da nihai terapötik amaçlardan biri danışanın senaryosunu analiz edip değiştirmesine yardım etmektir (Berne, 1958). Bu doğrultuda ilk adım danışanın senaryosunu keşfetmek yani onun erken dönem deneyimlerini, algılarını ve bunların zeminini oluşturan kültürünü anlamaya çalışmaktır. Farklı tarihe, kültüre ve dini inanca sahip insanlar hayatın anlamı, doğru-yanlış, kişisel sorumluk ve içsel-dışsal kontrol odağ1 temelinde çok farklı felsefelere sahiptir. Gültekin ve Voltan-Acar (2004) da aile ve toplumsal çevrenin etkileri, olanaklar ve dezavantajlar gibi birey düzeyindeki psikososyal birçok faktör göz önüne alınması konusunda TA uygulayıcılarını uyarmaktadırlar. Öyle ki özellikle dezavantajlı kültürel gruplara mensup kişiler üzerindeki çeşitli ön yargı ve ayrımcılık deneyimine maruz kalma gibi sistemik baskıların dikkate alınmadan yaşam planını değiştirmek adına sorumluluk almasının vurgulanması kültürel duyarlığa zıt bir yaklaşım olacaktır.

Nitekim, yaşam senaryosu kavramı doğası gereği de fenomenolojiktir yani bireyin algılarını yansitır. Senaryoların şekillenmesinde erken gelişimsel dönemin çok büyük etkileri olduğunundan, özellikle ebeveyn tutum ve mesajlarının (yasak/komutların) erken kararlar yoluyla bir yaşam senaryosuna dönüştüğünden bu makalede de bahsedilmiştir. Örneğin Kağıtçıbaşı (1970), Türk ve Amerikan ergenlerin anne baba tutumlarına yönelik algısını incelediği çalışmasında Türk ergenlerin daha fazla ebeveyn disiplini algıladığını ancak iki grubun ebeveynlerinden algılanan sevgi konusunda aralarında bir farklılık olmadığı ortaya çıkmıştır. Toplulukçu ve bireyci kültürel değerlerin anne baba tutumlarının çocuklar tarafından nasıl algılandığına ilişkin yapılan diğer çalışmalar da kontrol edici ya da disiplin uygulayan ebeveyn tutumlarının reddilme olarak algılanmadığı aksine eğer bu tutumlar yoksa bunun ilgizilik olarak bile algılandığı görülmüsşür (Bkz. Lansford, Deater-Deckard, Dodge, Bates ve Pettit, 2003; Trommsdorff, 1985). Bu araştırmalar bizlere danışanın kültürel özellikleri anlamadan danışanın yaşam planını doğru anlamayamayacağımızı göstermektedir. Ülkemiz kültürel değerleri ve genelde de toplulukçu değerlerin daha hâkim olduğu kültürlerden gelen danışanlarla çalışırken ebeveyne ve otorite ile ilişkileri ve kültürel saygıyı hesaba katmadan ebeveyn komutlarına direkt olarak karşı çıkmak kabul edici olmayabilir. Her ne kadar kısıtlıyacı olduğunu hissetse bunun ailesine bir saygısızlık veya ihanet olarak algılaması olası olabilir. Bu durumda senaryo analizi yapılırken daha yavaş hareket etmek faydalı olabilir. Danışana TA'nın dilini ve kavramların felsefesini iyi anlatmak; yaşam senaryosunda ve diğerleriyle kurduğu ilişkilerde tekrar eden kalıplarla ebeveyn komutlarının ve erken kararların bağlantısını danışanın özmümsemesine yardım etmek kolaylaştırıcı olabilir. Corey (2016) de TA yönelimli bir grup terapisinde liderleri, grup üyelerinin yaşam senaryolarına meydan okumadan önce güvenilir bir ilişki kurulduğundan ve danışanların da kendi aile miraslarını ve yaşantılarını sorgulamaya hazır olduklarından emin olmaları konusunda uyarmıştır. Bazı kültürlerde aile geleneklerinden kuşkulanmak, aile dışı bir grupta bu tür konulardan bahsetmek ya da sorgulanmak tabu sayılabilmektedir (Corey, 2016). Yaşam snaryolarının analizine dayanan çalışmalarda danışanın duygularıyla da çalışmak gerekli ve kaçınılmazdır, bu nedenle duyguların ifadesinde de kültürel farklıların olabileceği gözden kaçırılmamalıdır. Bazı tekniklerin kullanımında da bu hassasiyeti göstermek gereklidir. Örneğin, Transaksiyonel Analiz Terapisinde kullanılan bazı Gestalt tekniklerinin ve psikodrama gibi yaşantısal yöntemlerin Asya toplumları için çok uygun karşılanmayabileceğine dikkat çekilmiştir (Gültekin ve Voltan-Acar, 2004). 
Diğer yandan TA'nın ve Bern'in çokkültürlü gerçekleri reddeden bir perspektiften yaklaştığını söylemek de doğru olmaz, TA'yı geliştirdikten sonra Bern'in esas ilgisinin teorisinin ve pratiğinin kültürler arası etkililiğini göstermeye odaklandığına değilmiştir (Mazzetti, 2010a). Bu makalede ele alınan temelde TA'nın ilk ana dayanaklarıdır, elbette günümüze doğru TA'nın farklı bakış açıları ve yaklaşımlarla da bütünleştiridiği pek çok okulu olduğunu (Tudor ve Hobbes, 2007) ve psikolojik danışma ve psikoterapinin dördündü gücü olarak kabul edilen Çok Kültürlü Psikolojik Danışma Yaklaşımından (Sue, Arrendo ve McDavis, 1992) etkilendiğini söylemek mümkündür. Yaklaşımı çok kültürlülük temelinde ele alan çalışmalar artmıştır (Mazzetti, 2010b; Shivanath ve Hiremath, 2003). Çağdaş TA uygulayıcılarının çeşitli Berne'in formüle ettiği temel kavramların çoğunu değiştirdiği de belirtilmiştir (Corey, 2016). Nitekim her teori ve yaklaşımda olduğu gibi TA da geliştirildiği dönemin ve koşulların özellikleri yansıtmaktadır. Öyle ki ilk ortaya çıkışı 1960'lara dayanan bir yaklaşımdır ve birçok ana akım terapi yaklaşımı gibi kültürler arası farklılara yönelik bir perspektiften ziyade beyaz Avrupa toplum yapısı değelerinden köken aldığını söylemek mümkündür. Bu bakımdan yine ana akım terapi yaklaşımlarıyla paralel olarak özerklik, kişisel sorumluluk gibi batı değerlerini sağlıklı olmanın göstergeleri olarak kabul etmektedir. Ancak özerkliğin tümden bir bağımsızlık ya da ayrıklıkla, ilişkililiğin de bağımlılıkla eşdeğer olmadığını vurgulayan ve pek çok çalışma ile kapsamlı bir teori olulturan Kağıtçıbaşı (1996; 2013), bireylerde bu boyutların her birinde farklı ölçülerin bulunabileceğini belirtmiştir.

Son olarak TA odaklı bir psikolojik danışma sürecinde yaşam pozisyonlarının belirlenmesi, Ego Durumların analizi, psikolojik oyunlar ve yaşam senaryosu gibi kavramlara odaklanılmaktadır. Psikolojik danışma sürecinde danışana TA felsefesi ve terminolojisini öğretmek önemine değilmiştir, diğer yandan odağa alınan tüm kavramlar danışanın kişisel tarihine yani geçmişine, gelişimsel süreçlerine, algılarına ve etkileşim kalıplarına dayanmaktadır. Sözü edildiği gibi, tüm bu odaklar bireyin içinde büyüdüğü, geliştiği ve etkilendiği kültürden ayrı düşünülemez. Diğer yandan bu kavramları algılayan ve inceleyen çalışmanın diğer ortağı psikolojik danışmanın da kültürel arka planı sürece dahil olmaktadır. Bu noktada psikolojik danışmanın çok kültürlü yeterliklere sahip olmasının önemi ortaya çıkmaktadır. Kültürel olarak yetkin psikolojik danışmanlar insan davranışı, değerler, peşin hükümler, tutumlar, kişiser sınırlar vb. pek çok yöne ilişkin kişisel varsayımlarının, değerlerinin ve ön yargılarının aktif olarak farkında olmaya çalışırlar (Sue ve diğ., 1992). Kağnıcı (2019) psikolojik danışmanlar için kritik olan noktaların önyargılarını kabul etmesi, bunların dayanaklarını, kişisel yaşamına olan etkilerini ve en önemlisi de yardım sürecine olası etkilerinin farkında olmaya çalışmalarıdır. Bu farkındalık için psikolojik danışamanların kendilerine yöneltebilecekleri bazı sorular şunla olabilir: Kendi kültürel mirasımla ilişkili oluşturduğum anlamlar ve erken kararlar, hayata ve danışanıma karşı varsayımlarımı ve davranışlarımı nasıl şekillendiriyor olabilir? Bunlar danışanıma karşı beklenti ve varsayımlar, yani danışanın yaşam senaryosunun nasıl şekillendiğine ilişkin belli düşüncelere yöneltiyor olabilir mi? Sadece belirli bir kültürel gruptan geldiği için danışanımın o grubun tüm özelliklerine ilişkin bir yaşam senaryosuna sahip olabileceğine ilişkin bir ön varsayımım var mı? Danışanın benimle kurduğu transaksiyonların doğası incelerken iletişim kurmadaki kültürel özellikleri hesaba katıyor muyum?

\subsubsection{Katkulart}

TA temelde geleneksel psikanalitik kuramdan köken almasına karşın 50'li yılların hümanist akımlarından etkilenmekle birlikte güncel anlayışlara dayalı olarak terapide terapist ve danışan eşitliğine fazlasıyla önem vermektedir. Ayrıca bugün dünyada fazlaca kabul gören Bilişsel Davranışçı yaklaşımlardan da etkilendiği görülmekte ve terapiste çeşitli savunmaları olan danışanlarla da etkin 
çalışabilmesi için analitik yaklaşımdan daha fazla çözüm önerileri veren bir esneklik sağlamaktadır (Aydın, 2015).

Son 40 yıldan beri TA teorik, teknik, organizasyonel ve uluslararası ölçekte birçok yönden gelişmiştir (Summers ve Tudor, 2000). Günümüze kadar TA sekiz gelenek etrafında şekillenmiş ve gelişmiştir. Tudor ve Hobbes (2007) bu gelenekleri TA ile entegre edilen sistemlere göre: Klasik Okul (psikodinamik), Klasik Okul (Bilişsel-Davranışçı), Yeniden Karar Okulu (Gestalt Terapi), Kateksis Okulu (özellikle şizofreni olmak üzere psikiyatrik hastalıklarla çalışılan yaklaşımlar), Radikal Psikiyatri (Sosyal hareket ve radikal politikalar), Bütünleştirici (Gestalt ve Kendilik Psikolojisi) ve Yapılandırmacı (Lewin'in Alan Teorisi ve Friedman Öznelerarası Psikoterapisi) olarak sırlamışlardır. Benzer bir anlayışla TA birçok yaklaşımla bütünleştirilmeye de uygundur. Tudor ve Summers (2000) "Cocreative Transactional Analysis" adlı makalelerinde Alan Teorisi ve Sosyal Yapılandırmacılık yaklaşımlarından yararlandıkları, psikopatolojiden ziyade pozitif sağlı̆̆ 1 vurgulayan, terapötik ilişkide şimdi merkezli bir tutumu ve transaksiyonları, senaryoyu, ego durumları ve oyunları odağa alan Birlikte Yaratıcı Transaksiyonel Analiz (Cocreative Transactional Analysis) yaklaşımını ortaya atmışlardır. Ayrıca TA halihazırda var olan diğer yaşantısal yaklaşımlarla da kolayca bütünleştirilebilir. TA ve Gestalt terapinin kombinasyonu, TA'nın insanların analitik parçalarını ve bilişlerini vurgulaması ve Gestalt Yaklaşımının ise duyguları vurgulamasıyla özellikle etkilidir (Seligman, 2010).

TA yaklaşımı, çocuklar ve ergenler gibi çok çeşitli yaş gruplarından bireyler, aileler, eğitim, organizasyonlar ve grupla psikolojik danışma için pek çok uygulama alanına sahiptir. Başlangıçta sadece bireyler arası iletişimin değerlendirilmesiyle ilgilense de daha sonra ailelerin kompleks yapısının değerlendirilmesi için etkili yollardan biri olmuştur (Strzelczyk, 2015).

Bir diğer olumlu yönü, kolayca öğrenilebilir ve günlük yaşama da aktarılabilir olmasıdır. Çünkü iletişimdeki transaksiyonlar, ortaya çıkan ego durumları ve karşılıklı oynan oyunlar doğal ortamındadır, izole edilmiş değil başkalarılya iç içedir (Harris, 2017). Bu anlamda geleneksel terapilerden daha işlevsel ve pratik bir yaklaşım sunmaktadır.

Son olarak TA uygulayıcılarına eğitimci veya süpervizör olmaları için daha fazla eğitim almaları gereken bir yapı sunan az sayıda psikoterapi yaklaşımlarından biridir (Tudor, 2009). TA terapisti olmak için 250 saat ileri TA olmak üzere toplan 600 saat ders, TA onaylı eğitimcilerden 150 saat süpervizyon almak; 500 saati TA olmak üzere 1500 saat uygulama deneyimi ve TA terapisinden kişisel olarak yararlanmış olmak koşulları vardır (Akkoyun, 1995).

\subsubsection{Sinırlılıkları}

TA yaklaşımının sınırlıkların biri psikopatolojiye bakış açısıdır. Berne psikopatolojinin kişiler arasında yaşanan ya da yaşandığı varsayılan çeşitlere olaylara dayandığını savunmaktadır (Aydın, 2015). Patolojinin büyük kısmı ego durumları üzerinden tanımlanmaktadır. Bu nedenle psikopatolojide rol oynayan biyolojik boyutunun da göz ardı edildiği söylenebilir. Bazı uzmanlar kişilerarası ilişkilerde de bu tarz sınırlı bir yapı sunabileceğine değinmişlerdir. Farkındalık TA'da kişiler arası ilişkilerin temel motivasyonu olarak düşünülür. Bunlar sıklıkla kişinin erken yaşamında pozitif ya da negatif temas iletilerini ve insanlarla etkileşimlerinde oluşturdukları kalıpları anlamasını ifade eden "farkındalık sistemini” inşa etmesi olarak ifade edilir. Bu bakış açısı insanların bir şeyi neden yaptıkları ve neden diğerleriyle spesifik bir yolla iletişim kurduklarını açıklamada sınırlı, yani tek yönlü bir bakış açısı sunabilir. Çünkü insanların etkileşimlerindeki kültürel, biyolojik ve manevi yapıları göz ardı edebilir (Tudor ve Hobbes, 2007). Bir diğer sınırlık ise güçlü görünen basit dilin psikolojik oyunların yapısı ve 
dinamikleri ve çeşitli ego durumlarının alt bileşenleri gibi kavramların karmaşıklı̆̆ı konusunda danışanlar için zorluklar doğurabileceğidir (Corey, 2016). Yine Çocuk, Yetişkin ve Ebeveyn gibi terimlerin sıklıkla kullanılması bir süre sonra kavramların değerini düşürüp otomatik şekilde kullanılmalarına yol açabilir. Bu nedenle terimlerin kullanımında belli bir dengeyi korumak önemli olabilir. 


\section{KAYNAKLAR}

Akbağ, M. (2013). Psikolojik danışma/terapi sürecinde kontrat. Erişim adresi: http://dspace.marmara.edu.tr/handle/11424/1201. (Marmara Üniversitesi Açı Arşiv Sistemi) 12.03.2019'da alınmıştır.

Akbağ, M. ve Deniz, L. (2003). Öğretim elemanı ve öğretmen adaylarının birbirlerine yönelik algıları: Transaksiyonel analiz açısından bir değerlendirme. Kuram ve Uygulamada Ĕ̌itim Bilimleri, 3(2), $263-293$.

Akkoyun, F. (1993). Saygı kavramına transaksiyonel analiz (TA) açısından bakış. Türk Psikolojik Danışma ve Rehberlik Dergisi, 1(4).

Akkoyun, F. (1995). Transaksiyonel analize giriş. Ankara: 72 TDFO Ltd. Şti.

Akkoyun, F. (2007). Transaksiyonel analiz. İstanbul: Nobel Yayın Dağıtım.

Akkoyun, F. (2011). Transaksiyonel analiz: Psikolojide işlemsel çözümleme yaklaşımı. Ankara: Nobel Yayın Dağıtım.

Alisinanoğlu. F. ve Köksal, A. (2000). Gençlerin ben durumları (ego state) ve empatik becerilerinin incelenmesi. Hacettepe Üniversitesi Eğitim Fakültesi Dergisi, 18, 11-16.

Aydın, E. (2015). Transaksiyonel analiz terapisi. İçinde E. H. Türkçapar ve E. Köroğlu (Ed.), Psikoterapi yöntemleri-kuramlar ve uygulama yönergeleri (s. 215-229). (2. Bask1), Ankara: HYB Yayınları.

Berne, E. (1958). Transactional Analysis: A new and effective method of group therapy. The American Journal of Psychotherapy, 12, 735-743.

Berne, E. (1972). What do you say after you say hello? New York: Grove Press.

Berne, E. (1996). Principles of transactional analysis. Indian J. Psychiatry, 38(3), 154-159.

Berne, E. (2001). Hayat denen oyun. (S. Sargut, Çev.), İstanbul: Kariyer Yayıncılık.

Berne, E. (2015). Insanların oynadı̆̆ı oyunlar. (H.Ü. Haktanır Çev.), İstanbul: Koridor Yayıncılık.

Beycan Ekitli, G. (2013). Huzurevlerinde yaşayan yaşlıların yaşam doyumları ile ego durumları arasındaki ilişkinin incelenmesi. Yayımlanmamış Yüksek Lisans Tezi, Ege Üniversitesi, İzmir.

Buluş, M. ve Atan, A. (2016). Öğretmen adaylarında ego durumlarının bağlanma stillerini yordama gücü. Ege Ĕ̈itim Dergisi, 1(17), 36-61.

Corey, G. (2016). Theory and practice of group counseling. USA: Brooks/Cole Publishing.

Clarkson, P. (1993a). Transactional analysis psychotherapy: An integrated approach. New York: Routledge.

Clarkson, P. (1993b). Transactional Analysis as a Humanistic Therapy. Transactional Analysis Journal, 23(1), 3641. https://doi.org/10.1177/036215379302300104

Çatak, E. (2012). İlköğretim okulu öğretmenlerinin yöneticilerinde gözlemledikleri ego durumları ile örgütsel güven arasındaki ilişki. Yayımlanmamış Yüksek Lisans Tezi, Maltepe Üniversitesi, İstanbul.

Goulding, R. ve Goulding, M. (1976). Injunctions, decisions and redecisions. Transactional Analysis Journal 6(1), 41-48.

Gökçen, G. (2009). Alkol bağımlıları ve sosyal içicilerin ego durumları, çocukluk kararları ve psikolojik uyum açısından incelenmesi. Yayımlanmamış Yüksek Lisans Tezi, Ege Üniversitesi, İzmir.

Gültekin, F. ve Voltan-Acar, N. (2004). Transaksiyonel analizin Türk kültürüne uygulanabilirliği: Kültür açısından eleştirel bakış. Eğilim ve Bilim, (29)133, 28-38.

Harris, T. A. (2017). Ben Ok'im- Sen Ok'sin. (H. Uğur, N. Sağlam ve D. Akıncı, Çev.) İstanbul: Okuyan Us Yayınlar1.

Hackney, H. ve Cormier, S. (2008). Psikolojik danışma ilke ve teknikleri: Psikolojik yardım süreci el kitabı. (T. Ergene ve S. Aydemir Sevim Çev.). Ankara: Mentis Yayıncılık.

İkiz, F. E. (2016). Psikolojik Danışma ve Psikoterapide Kuramlar ve Yenilikçi Yaklaşımlar. Ankara: Nobel Akademik Yayıncılık.

Johnsson, R. (2011). Transactional analysis psychotherapy-three methods describing a transactional analysis group therapy. Doctoral dissertation, Lund University, Swedish. 
Kaçar, B. (2008). Lise öğrencilerinin karar stratejileri ve transaksiyonel analiz ego (ben) durumlarının bazı değişkenler açısından incelenmesi. Yayımlanmamış Yüksek Lisans Tezi, Marmara Üniversitesi, İstanbul.

Kağıtçıbaşı, Ç. (1970). Social norms and authoritarianism: A Turkish-American comparison. Journal of Personality and Social Psychology, 16, 444-451.

Kağıtçıbaş1, Ç. (1996). The autonomous-related self: A new synthesis. European Psychologist, 1(3), 180-186.

Kağıtçıbaşı, Ç. (2013). Adolescent autonomy-relatedness and the family in cultural context: What is optimal? Journal of Research on Adolescence, 23(2), 223-235.

Kağnıc1, D. Y. (2019). Kültür ve psikolojik danışma. Ankara: Pegem Akademi Yayıncılık

Karababa, A. ve Dilmaç, B. (2016). Ergenlerde yalnızlığın yordayıcıları olarak TA ve değerler. Eğitim ve Bilim. 41(187), 63-77.

Keçeci, A. (2007a). Hemşirelik yüksek okulu ögrrencileri ve ögrretim üyeleri arasindaki iletişimin transaksiyonel analiz ego durumları açısından değerlendirilmesi. Doktora Tezi, İstanbul Üniversitesi, İstanbul.

Keçeci, A. (2007b). Hemşirelik eğitiminde iletişime yeni bir yaklaşım: Transaksiyonel analiz. Uluslararası İnsan Bilimleri Dergisi, 4(2).

Lansford, J. E., Deater-Deckard, K., Dodge, K. A., Bates, J. E. ve Pettit, G. S. (2003). Ethnic differences in the link between physical discipline and later adolescent externalizing behaviors. Journal of Child Psychology and Psychiatry, 44, 1-13.

Mazzetti, M. (2010a). Eric Berne and cultural script. Transactional Analysis Journal, 40, 187-195.

Mazzetti, M. (2010b). Cross-cultural transactional analysis. The Psychotherapist, 46, 23-25.

Murdock, N. L. (2016). Psikolojik danışma ve psikoterapi kuramları-olgu sunumu yaklaşımıyla. (F. Akkoyun, Çev.) Ankara: Nobel Akademik Yayıncilık.

Özerk, H. (2008). Özel okul yöneticilerinden ve ögretmenlerinden, transaksiyonel analiz kuramı çerçevesinde, birbirlerinde gözlemledikleri ve birbirlerinde bekledikleri ego durumları'nın karşılaşstırılması. Yayımlanmamış Yüksek Lisans Tezi, Yeditepe Üniversitesi, İstanbul.

Rotondo, A. (2020). Rethinking contracts: The heart of eric berne's transactional analysis. Transactional Analysis Journal, 50(3), 236-250. https://doi.org/10.1080/03621537.2020.1771032

Seligman, L. (2010). Therories of counseling and psychoteraphy: Systems, strategies and skills. New Jersey: Pearson, Prentice Hall.

Sevim, A. S. (1996). Transaksiyonel analize dayalı bir eğitim programının evli çiftlerin ego durumları ve evlilik yaşamlarına iliş̧kin bazı değişkenlere etkisi Yüksek Lisans Tezi, Ankara Üniversitesi, Ankara.

Shivanath, S. ve Hiremath, M. (2003). The psychodynamics of race and culture. In C. Sills \& H. Hargaden (Eds), Ego states (pp. 169-184). London: Worth Publishing.

Solomon, C. (2003). Transactional analysis theory: The basics. Transactional Analysis Journal, 33(1), 15-22. https://doi.org/10.1177/036215370303300103

Söylemez, N. (2017). Beyaz yakalı çalışanların kendilerinde algıladıkları ego durumu ile yöneticilerinde algıladıkları ve bekledikleri ego durumları bağdaşımının (uyumunun) iş doyumları ile ilişskisi. Yüksek Lisans Tezi, Arel Üniversitesi, İstanbul.

Steiner, C. (1990). Scripts people live: Transactional analysis of life scripts. New York: Grove Press.

Stewart, I. (1996). Developing transactional analysis counselling (Developing counselling series). London: SAGE Publications.

Stewart, I. (2013). Transactional analysis counselling in action (Counselling in action series) (4 edition), London: SAGE Publications.

Strzelczyk, D. (2015). Transactional analysis as a method to test the quality of life of a family pedagogika. Family Pedagogy, 5(1), 27-38. https://doi.org/10.1515/fampe-2015-0003.

Sue, D. W., Arredondo, P., \& McDavis, R. J. (1992). Multicultural counseling competencies and standards: A call to the profession. Journal of Multicultural Counseling and Development, 20(2), 64soyut88. https://doi.org/10.1002/j.2161-1912.1992.tb00563.x 
Summers, G., ve Tudor, K. (2000). Cocreative transactional analysis. Transactional Analysis Journal, 30(1).

Torun, E. (2015). Madde kullanım öyküsü olan mahkumların ego durumları ve çocukluk dönemi açısından incelenmesi. Yayınlanmamış Yüksek Lisans Tezi, Ege Üniversitesi Sağlık Bilimleri Enstitüsü, İzmir.

Trommsdorff, G. (1985). Some comparative aspects of socialization in Japan and Germany. I. R. Lagnues ve Y. H. Poortinga, (Ed.), From a different perspective: Studies of behaviors across cultures içinde (231-240). Lisse: Swets \& Zeitlinger.

Tudor, K. (2009). "In the manner of": Transactional analysis teaching of transactional analysts. Transactional Analysis Journal, 39(4).

Tudor, K., ve Hobbes, R. (2007). Transactional analysis. In W. Dryden (Ed.), The handbook of individual therapy (5th ed.) (pp. 256-286). London, UK: Sage.

Tüfekçi, S. (2008). Romantik ilişkilerde genç yetişkinlerin aşka ilişkin tutumları ve kişilik özellikleri: Transaksiyonel Analiz ego durumları açısından bir değerlendirme. Yayımlanmamış Yüksek Lisans Tezi. Marmara Üniversitesi, İstanbul.

Widdowson, M. (2016). Transactional analysis for depression: A step-by-step treatment manual. Routledge/Taylor \& Francis Group.

Yılmaz, F. E. (2014). Evli bireylerin ego durumları ile evlilik uyumları ve çocuklarının okul başarısı arasındaki ilişkinin incelenmesi. Yayımlanmamış Yüksek Lisans Tezi. Marmara Üniversitesi, İstanbul.

Yönder, M. (2012). Psikiyatri kliniğinde çalışan hemşirelerin Transaksiyonel Analiz kuramına göre ego durumları. Yayımlanmamış Yüksek Lisans Tezi, Düzce Üniversitesi, Düzce. 


\section{EXTENDED ABSTRACT}

Transactional Analysis is an approach that deals with a wide range of human psychology such as personality structuring, interpersonal relationships and communication, development, psychopathology, and psychotherapy (Akkoyun, 1995). Transactional Analysis present a systematic approach that aims to help individuals change their childhood scenarios, in other words, their life decisions that take shape in early childhood and continue in the flow of life but disrupt their current lives. In addition to this aim, another basic aim of Transactional Analysis is to make individuals aware of the dominant structures they present about problems that arise in interpersonal relations. It is remarkable that there isn't enough study regarding Transactional Analysis Therapy in studies in our country. In addition, there is limited amount of review study examining TA comprehensiveley. The aim of this article is to provide a holistic overview of TA. In this direction, the perspective of human nature, its basic concepts, view of psychopathology, therapeutic goals, the role and function of the therapist, therapeutic techniques and methods were included, and then the approach was evaluated in terms of multiculturalism and the limitations of the approach were mentioned. For this purpose, literature research has been conducted by using research articles and books introducing and examining Transactional Analysis in our country and abroad.

Transactional Analysis was created by Eric Berne (1910-1970), a Canadian psychiatrist who studied psychoanalysis (Clarkson, 1993a). Historically, the philosophical and intellectual foundations of the approach were based on phenomenology, empiricism, existentialism and humanism (Tudor \& Hobbes, 2007; Clarkson, 1993a). Eric Berne had received education on psychoanalysis, and had also been impressed by Sigmund Freud in his professsional works (Söylemez, 2017), but he had developed a system that could explain assumptions about human behaviour with everyday language and thus make apply them on daily life (Akkoyun, 1993). However, Transactional Analysis differs from Classical Psychoanalytic Approach at many points. The most important point of this distinction is view of human nature. Transactional Analysis see client at equal point with therapist, and active, and also places client in the center of therapy (Clarkson, 1993a). Although the concept of instinct is not rejected, it is asserted that the child's main motivation is contact with parents rather than sexual or destructive impulses. However, is drawn attention to the environment in which the child is approved, and it is assumed that child can only meet their needs if receives approval of their parents (Aydın, 2015). According to the main assumptions of Transactional Analysis, every person has a tendency to develop emotionally, gain autonomy and make choices (Akkoyun, 1995; Tudor, 2009). People are born well (I'm OK-you're OK) and every individuals has the capacity to think. In addition to the emphasis on early decisions, a fundamental assumption about change is that people are not the victims of decisions making in childhood, and can be changed and shaped them if they wish (Gökçen, 2009). Berne indicated that each inner experinces that start at birth and even before birth was an "ego state". These stuctures are expressed as adaptive system of emotions and a range of adaptive set of behaviors (Berne, 1961;2001). Ego states are examined at two distinct models as structural analysis and functional analysis (Akkoyun, 2011; Berne, 1958). According to structure analysis, "Parent", "Adult" and "Child" are present at all individual's personality (Solomon, 2003). Patterns of emotions, thought and behavior that they learned from parents or parent figures in their life are as expressed Parent ego state (Keçeci, 2007b; Solomon, 2003). Child ego state consists of all early childhood experiences. Every individual has a part that feels, thinks and acts as when you were a kid (Harris, 2017). Adult ego state observes, pays attention, and accepts messages from the other ego status, and evaluate these data by compares with reality, and then makes their decision (Widdowson, 2016). In addition, Adult ego state encompasses a set of autonomous emotion, thought and behaviour (Akbağ 2000; Akkoyun 2001). The Parental ego state in functional 
analysis is divided into two as Nurturing Parent and Critical Parent. The Child ego state is also divided into two as Adapted Child and Natural (Free) Child (Solomon, 2003).

The life scenario is an unconscious life plan based on the decisions the child makes for herself, life and others, shaped in early childhood (Harris, 2017; Solomon, 2003). However, without awareness of early decisions, patterns that prove the correctness of these decisions are repeated in a cycle (Solomon, 2003). Another important concept of Transactional Analysis Therapy is transaction. Berne (2015) defined transaction as basic unit of social relationship. Transactions are related to which ego state directed the individual, and which ego state in the other person executed the response in communication (Solomon, 2003). In this direction, Berne (1961) indicated three transactions as complementary, crossed and latent. Complementry transactions represent normal and healthy human interactions. Also interactions will proceed as long as transactions are complementary. However, crossed and latent transactions are unhealthy human interactions and it isn't seem possible that communication continues. Because either an ego state different than the ego state which received the stimuli is the one that responds (crossed transaction), or transmisson carries psychological messages (latent transaction).

Explanation of the pathology in the Transactional Analysis approach is defined by ego states. Basicly, the three ego states are in a state of equilibrium in the individual's personality. However, if a person is rigidly attached to one or two ego states, or if one ego state contaminates or insides on another, the person is likely to develop difficulties, especially in relationships (Seligman, 2010). Accordingly, two functional problems are: "Contamination" and "Exclusion" (Harris, 2017; Aydın, 2015). Scenario ise one of the important concept of Transactional Analysis Therapy. Just as Adler, Berne also believed that individuals shaped scenarios directing their life in childhood (Seligman, 2010).

Primary aim of Transactional Analysis Therapy is that individuals build and develop meaningful relationship (Tudor \& Hobbes, 2007). It is important to make each client an expert who can analyzes their own transactions. Besides, other main purpose of therapy is to empower the Adult is to make it free and autonomous. Therapists play a flexible role that adapt between client need and therapy process in Transactional Analysis Therapy (Clarkson, 1993a). Contract is accepted fundamental technique. The nature of therapy, the roles and responsibilities of client and therapist are explained in the contract (Seligman, 2010). In addition to contract, many different techniques are also used (İkiz, 2016; Gültekin \& Voltan-Acar, 2004; Hackney \& Cormier, 2008). Although Transactional Analysis derives mainly from traditional psychoanalytic theory, it is influenced by the humanist movements of the 50s, and gives great importance to therapist and client equality in therapy based on current understanding. Approach posseses many application area such as children, adolesence, families, education, organizations and psycohological counseling groups. The main point that researchers see as limitation in therapy is that pathology is defined largely through ego states (Tudor \& Hobbes, 2007).

Transactional Analysis is quite compherensive approach including many concepts. It is an appropriate approach to working with individuals from a variety of cultures because it focuses on communication and sees each individual as unique in using the ego state. In addition, one of the ultimate therapeutic goals in TA is to help the client analyze and change his scenario (Berne, 1958). In this direction, the first step is to discover the scenario of the client, that is to try to understand his/her early experiences, perceptions and the culture that underlies them. Therefore, sensitive to the multicultural perspective, it is also important not to ignore cultural characteristics during the practices for the effectiveness of therapy. 